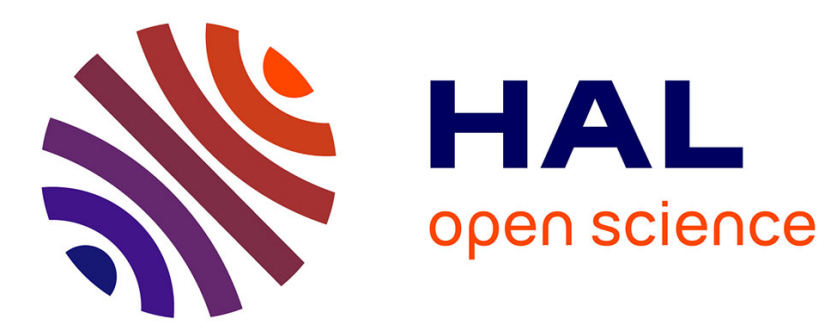

\title{
The Histone H3 Family and Its Deposition Pathways
}

\author{
Dominique Ray-Gallet, Geneviève Almouzni
}

\section{To cite this version:}

Dominique Ray-Gallet, Geneviève Almouzni. The Histone H3 Family and Its Deposition Pathways. Advances in Experimental Medicine and Biology book series. Histone Mutations and Cancer, 1283, Springer Nature, pp.17-42, 2020, Advances in Experimental Medicine and Biology b, 978-9-81-1581038, 978-9-81-158104-5. 10.1007/978-981-15-8104-5_2 . hal-03028662

\section{HAL Id: hal-03028662 https://hal.science/hal-03028662}

Submitted on 27 Nov 2020

HAL is a multi-disciplinary open access archive for the deposit and dissemination of scientific research documents, whether they are published or not. The documents may come from teaching and research institutions in France or abroad, or from public or private research centers.
L'archive ouverte pluridisciplinaire HAL, est destinée au dépôt et à la diffusion de documents scientifiques de niveau recherche, publiés ou non, émanant des établissements d'enseignement et de recherche français ou étrangers, des laboratoires publics ou privés. 


\title{
Title Book: Histone Mutations and Cancer
}

\section{Chapter 2: The histone H3 family and its deposition pathways}

\author{
Dominique Ray-Gallet and Geneviève Almouzni \\ Institut Curie, PSL Research University, CNRS, UMR3664, F-75005 Paris, France \\ Sorbonne Université, Institut Curie, CNRS, UMR3664, F-75005 Paris, France
}

Corresponding author: genevieve.almouzni@curie.fr

\begin{abstract}
Within the cell nucleus, the organization of the eukaryotic DNA into chromatin uses histones as components of its building block, the nucleosome. This chromatin organization contributes to the regulation of all DNA template-based reactions impacting genome function, stability and plasticity. Histones and their variants endow chromatin with unique properties and show a distinct distribution into the genome that is regulated by dedicated deposition machineries. The histone variants have important roles during early development, cell differentiation and chromosome segregation. Recent progress has also shed light on how mutations and transcriptional deregulation of these variants participate in tumorigenesis. In this chapter we introduce the organization of the genome in chromatin with a focus on the basic unit, the nucleosome, which contains histones as the major protein component. Then we review our current knowledge on the histone $\mathrm{H} 3$ family and its variants - in particular $\mathrm{H} 3.3$ and $\mathrm{CenH} 3^{\text {CENP-A }}$ focusing on their deposition pathways and their dedicated histone chaperones that are key players in histone dynamics.
\end{abstract}




\section{Keywords}

Chromatin, Nucleosome, Histone, Histone Variant, Histone Chaperone, Histone Deposition

\begin{tabular}{ll}
\multicolumn{2}{l}{ Abbreviations } \\
ChIP-seq & chromatin immunoprecipitation sequencing \\
DSC & DNA synthesis coupled \\
DSI & DNA synthesis independent \\
ES & embryonic stem \\
KO & knockout \\
NCP & nucleosome core particle \\
PTM & post-translational modification
\end{tabular}

\subsection{Introduction}

\subsubsection{Chromatin}

The term chromatin (from the Greek chrôma, "color") emerged in the 1880s when Flemming found a structure in the cell nucleus that strongly absorbed basophilic dyes [1]. Chromatin is a complex nucleoprotein structure comprising mainly DNA (Deoxyribonucleic acid) and basic proteins (histones). DNA is the heritable genetic material (genome) which consists of about three billion base pairs distributed into 46 chromosomes per cell in human. This material representing about two meters of DNA is confined in each cell in a nuclear compartment of few micrometers in diameter. Thus, chromatin organization ensures to compact DNA from the basic unit, the nucleosome, up to higher level of architecture. Chambon and Kornberg discovered in the 1970s the nucleosome as a repeating unit for the organization of chromatin $[2,3]$. This nucleosome comprises about 147 bp (base pairs) of DNA wrapped around a core histone octamer flanked by 20-90 bp of a linker DNA associated with the linker histone H1. The complex 147 bp DNA-core 
histone octamer (without the linker DNA and $\mathrm{H} 1$ ) constitutes the nucleosome core particle (NCP). The core histone octamer consists of two copies of each core histone $\mathrm{H} 3, \mathrm{H} 4, \mathrm{H} 2 \mathrm{~A}$ and $\mathrm{H} 2 \mathrm{~B}$ organized into a $(\mathrm{H} 3-\mathrm{H} 4)_{2}$ tetramer flanked by two $(\mathrm{H} 2 \mathrm{~A}-\mathrm{H} 2 \mathrm{~B})$ dimers. Resolution of the crystal structure of the nucleosome core particle at $2.8 \AA$ in 1997 revealed how histones interact with each other and with DNA, and how their amino-terminal tails protrude out of the particle [4]. The nucleosome array forms a $10 \mathrm{~nm}$ (nanometer) diameter fiber that resembles "beads on a string" [5]. In the cell, this fiber undergoes different levels of compaction to form the higher order chromatin structure. In 1928, Heitz observed in the cell nucleus two different types of regions with a light microscope, discrete highly condensed regions and dispersed lightly packed regions that constitute two types of chromatin, heterochomatin and euchromatin, respectively [6]. Constitutive heterochromatin mainly consists of repetitive DNA sequences that do not contain genes such as telomeres, centromeres and pericentromeres, whereas euchromatin is mainly comprised of the coding part of the genome harboring genes. Recent progress with chromatin capture technologies has further revealed levels of chromatin organization with interacting chromatin loops and topologically associating domains (TADs) which serve as functional platforms for physical interactions between regulatory elements $[7,8]$.

Beyond DNA compaction, chromatin organization influences all nuclear functions. Indeed, chromatin is the substrate for the different processes operating on DNA such as replication, transcription and repair. Thus a proper control of the dynamics of this organization ensures accurate genome function [9-11]. This control is exerted at all levels from the DNA and histones within the nucleosome particle up to the higher order chromatin architecture in the cell nucleus [12]. 


\subsubsection{Histones}

Histones are small basic proteins that are among the most conserved in eukaryotes [13]. The core histones from the $\mathrm{H} 2 \mathrm{~A}, \mathrm{H} 2 \mathrm{~B}, \mathrm{H} 3$ and $\mathrm{H} 4$ families range in size from $11 \mathrm{kDa}$ to $15 \mathrm{kDa}$ while the linker histones from the $\mathrm{H} 1$ family are around $21 \mathrm{kDa}$. A structurally conserved motif called histone-fold domain is present in all core histones. It consists of three $\alpha$-helices $(\alpha 1, \alpha 2$ and $\alpha 3)$ connected by short loops L1 and L2 that mediate heterodimeric interactions between the core histones [14]. The unstructured N-terminal extremity that extends at the surface of the nucleosome is the main region of the histone which is subjected to post-translational modifications (PTMs) with important consequences on chromatin functions [15]. Numerous PTMs include acetylation, phosphorylation, methylation, ubiquitylation, crotonylation and the latest described serotonylation [16]. As schematic examples, tri-methylation of the lysine 9 of histone H3 (H3K9me3) mainly associates with silenced regions in the genome while trimethylation of the lysine 4 of histone $\mathrm{H} 3(\mathrm{H} 3 \mathrm{~K} 4 \mathrm{me} 3)$ generally correlates with transcriptionally active regions. These histone PTMs do generally occur in various combinations that gave rise to the hypothesis of a histone code where these modifications would work sequentially and/or together $[17,18]$. They can either modulate the physical properties of the nucleosome and/or regulate the binding of protein partners that recognize specific modifications or RNA and possibly alter higher order structure. The histone PTMs are most often reversible providing a system to react to external stimuli for short term response, as part of a signaling module. They can also be maintained over cellular divisions and thereby function as a memory module of "epigenetic" nature. Furthermore, as we will discuss, in addition to these PTMs, the choice of distinct histone variants to form a nucleosome particle offers not only various provision of histones but also another way to alter the nature of the NCP with impact on chromatin function. 


\subsubsection{Replicative Histones and Histone Variants}

In most eukaryotes, two types of histones exist for each histone family, the replicative and the non-replicative histones, the latter commonly referred to as non-allelic histone variants [19]. The replicative histones exhibit a high peak of expression during $S$ phase when the doubling of genomic content requires a massive provision of histones. The genes of replicative histones show a peculiar organization in clusters that comprise multiple copies of all core histones and the $\mathrm{H} 1$ histone linker $[20,21]$. This unique genomic organization and regulation at multiple levels contribute to optimize coregulation which is essential for the need of a high peak of expression of replicative histones during S phase. These histone clusters lack introns, have relatively short UTRs, and produce transcripts that do not undergo polyadenylation and harbor a conserved 3' stem-loop structure which is required for the regulation of mRNA stability [22]. The existence of non-allelic variants for $\mathrm{H} 2 \mathrm{~A}, \mathrm{H} 2 \mathrm{~B}$ and $\mathrm{H} 3$ in mammals was first uncovered in 1977 when resolving histones on polyacrylamide gel electrophoresis in presence of non-ionic detergents (Triton Acid Urea gels) [23]. In contrast with replicative histones, the expression of histone variants does not increase during $S$ phase and each variant harbours a unique temporal expression. They are encoded by multi-exon genes located outside of histone clusters. Transcripts lack 3' stem-loop and undergo conventional processing through splicing and polyadenylation like most other RNA polymerase II (Pol II) transcripts. The protein sequence of a histone variant is either extremely similar or divergent from its replicative counterparts. Importantly, not only the expression but also the deposition pathways for the replicative histones and the histone variants are distinct. The replicative histones are incorporated into chromatin in a DNA synthesis coupled (DSC) manner. This occurs mainly at replication forks during $S$ phase when vast amounts of newly synthesized histones are required to ensure chromatin restoration on the duplicated genome. In contrast, the histone variants are incorporated into chromatin in a DNA synthesis independent (DSI) manner. Their mode of deposition onto DNA and their location in the genome are in general specific for each histone variant [24]. 
The deregulated expression of histone variants and histone chaperones in various cancers shed light on the importance to connect chromatin and genome stability $[25,26]$. The discovery of $\mathrm{H} 3$ mutations in pediatric glioblastomas attracted attention on histone variants in cancer development $[27,28]$. In particular, mutations of histone $\mathrm{H} 3$ at K27M and G34V/R known as "oncohistones" were put forward as major drivers in these glioblastomas [29-32]. Since then, a considerable number of histone mutations - higher than previously recognized- has been identified in human tumours [33]. An increased interest has thus arisen in exploring the histones of the $\mathrm{H} 3$ family in greater details along with their modes of incorporation into chromatin by their dedicated chaperones. Progress in this field is therefore of critical importance for understanding normal development and disease like cancer [25].

\subsection{The Histone H3 Family}

To date in human, eight members constitute the histone $\mathrm{H} 3$ family, two replicative histones (H3.1 and H3.2) and six histone variants. Among these $H 3$ variants, limited information exists for the testis-specific H3.4 (H3.1t) [34], the hominid-specific H3.5 [35] and the two primate-specific H3.X and H3.Y [36]. Thus, we will focus on the H3.1 and H3.2 replicative histones and H3.3 and CenH3 $3^{\text {CENP-A }}$ histone variants which have been explored in more details.

\subsubsection{Replicative H3.1 and H3.2}

The two replicative histones $\mathrm{H} 3, \mathrm{H} 3.1$ and $\mathrm{H} 3.2$, are encoded by several genes in clusters (Fig. 2.1). They differ by only one residue at position 96 (Fig. 2.2A). Most studies have focused on $\mathrm{H} 3.1$ as the representative of $\mathrm{H} 3$ replicative histone in mammals, yet $\mathrm{H} 3.2$ is the most common replicative histone in eukaryotes. $\mathrm{H} 3.1$ is present only in mammals in addition to H3.2. Despite their high similarity, in human, some functional specificity was suggested based on differences in both expression patterns and associated PTMs [37]. As expected for replicative histones, both H3.1 and H3.2 are incorporated into chromatin at replication forks during S phase in a DSC manner in order to duplicate chromatin of the replicated DNA [38-40]. Moreover, deposition of 
H3.1 outside of S phase occurs at sites of DNA synthesis as observed at UV damaged sites [41]. Indeed, the DNA repair process leads to histones eviction to allow access to the repair machinery and repaired coupled incorporation of H3.1 participates to the chromatin restoration [42]. This is accompanied by a recycling of pre-existing histones (Adam et al, 2017).

\subsubsection{H3.3 Variant}

The histone variant $\mathrm{H} 3.3$ is encoded by two single genes in mammals (Fig. 2.1). It is closely related to H3.1 and H3.2 with only five and four amino acid residue differences, respectively (Fig. 2.2 A). One difference concerns the residue 31 in the $\mathrm{N}$-terminal tail of the histones with a serine in H3.3 instead of an alanine in both $\mathrm{H} 3.1$ and $\mathrm{H} 3.2$. This serine 31 in $\mathrm{H} 3.3$ is phosphorylated during mitosis [43] and at transcribing regions in mouse activated macrophages [44], however the exact role of this modification remains elusive. The three other different residues AIG, located in the $\alpha 2$ helix of the histone fold (at positions 87,89 and 90 ), are important for specific histone chaperone recognition and the choice of a deposition pathway. An evolutionary analysis suggested that $\mathrm{H} 3.3$ is the ancestral form of the replicative $\mathrm{H} 3.1 / 2$ and in budding yeast the unique non-centromeric histone $\mathrm{H} 3$ is closely related to $\mathrm{H} 3.3$ [19]. However, recent work to "humanize" histones in budding yeast showed that adaptation to H3.1 proved easier in yeast compared to H3.3 in the context of a fully humanized nucleosome [45]. In mammals, two paralogous genes, $\mathrm{H} 3.3 \mathrm{~A}$ and $\mathrm{H} 3.3 \mathrm{~B}$, encode the same $\mathrm{H} 3.3$ protein but have different codons (could impact the folding) and distinct untranslated regions (could impact transcription regulation) (Fig. 2.1). This suggests that a distinct transcriptional and post-transcriptional regulation of these two genes could provide different patterns of expression among tissues and during development [46-48]. The H3.3 variant present throughout the cell cycle was first described for its high level of incorporation at active rDNA arrays independently of replication in Drosophila [38]. H3.3 is deposited onto DNA in a DSI manner during interphase (G1, S and G2 phases). $\mathrm{H} 3.3$ is the histone $\mathrm{H} 3$ predominantly present in chromatin of cells that are not dividing like quiescent or post-mitotic cells, due to its capacity to be incorporated in a pathway 
independent of DNA synthesis [49-51]. Moreover, upon fertilization and concomitantly with protamines removal, a major reprogramming involves H3.3 incorporation in paternal chromatin before the first round of DNA replication in both Drosophila and mouse [52-54]. The genome wide distribution of $\mathrm{H} 3.3$ variant as observed by ChIP-seq analysis in mammalian cells shows a distinct pattern. Enriched in euchromatin at active genes, $\mathrm{H} 3.3$ presence is most often correlated with active transcription [55]. More precisely, H3.3 accumulates throughout the body of active genes but also at promoter regions at both active and inactive genes and at genic and intergenic regulatory regions in ES cells. In addition, a significant contribution of this variant is also revealed through enrichment in heterochromatin at both telomere and pericentric heterochromatin in ES cells [55,56]. Remarkably, the crystal structure of human nucleosome core particles containing $\mathrm{H} 3.1, \mathrm{H} 3.2$ or $\mathrm{H} 3.3$ revealed identical structures suggesting a common function in the organization at the level of individual particles (Fig. 2.2 B) [57]. However, H3.3 containing nucleosomes in vivo appear more sensitive to salt-dependent disruption [58], arguing that the presence of this variant, the associated PTMs or combination with other variants (such as $\mathrm{H} 2 \mathrm{AZ}$ ) may change the properties of the nucleosome towards a more open/active chromatin [59]. Importantly, morpholino experiments revealed a critical role for $\mathrm{H} 3.3$ during early development in $X$. laevis [60]. In mice, a double-KO of the two genes (H3.3A and H3.3B) results in impaired development and embryonic lethality, no double-KO embryo surviving after stage E8.5 [47]. These defects are proposed to result from heterochromatin structures dysfunction at telomeres and centromeres leading to mitotic defects [47]. How this is entailed remains to be deciphered since it is unclear to which extent these phenotypes arise from the provision of the variant, the deposition mode or the final organization involving the variant or a combination.

\subsubsection{CenH3 ${ }^{\text {CENP-A }}$ Variant}

In 1985, Earnshaw and Rothfield identified CenH3 ${ }^{\text {CENP-A }}$ as one of the proteins detected by autoantibodies from patients with CREST (calcinosis, Reynaud syndrome, oesophageal dysmotility, sclerodactyly, telangiectasia) [61]. Then, in 1991 Palmer et al. demonstrated that 
CenH3 $3^{\text {CENP-A }}$ is a distinctive histone, with some sequences similarity to $\mathrm{H} 3$ [62]. This distant histone $\mathrm{H} 3$ variant was also called "deviant" given the fact that many segments are not related to $\mathrm{H} 3$ [63]. The histone variant $\mathrm{CenH} 3^{\mathrm{CENP}-\mathrm{A}}$ is encoded by a single gene (Fig. 2.1) and exhibits less than $50 \%$ of amino acid sequence identity with its replicative counterparts $\mathrm{H} 3.1 / 2$ and is highly divergent in various species (Fig. 2.2 A). This low level of conservation is in line with a rapid evolution of centromere organization and its components [64]. While $\mathrm{H} 3.1$ and $\mathrm{H} 3.3$ nucleosomal structures are almost identical, the more compact $\mathrm{CenH} 3^{\mathrm{CENP}-\mathrm{A}}$ nucleosome only wraps $121 \mathrm{bp}$ of DNA, and this may impact further the higher-order chromatin organization in these regions (Fig. 2.2 B) [65-67]. In human, expression of new CenH3 ${ }^{\text {CENP-A }}$ occurs in G2/M phases. Its incorporation into chromatin is restricted to late mitosis (telophase)/early G1 by a DSI pathway, leading to centromeric $\mathrm{CenH} 3^{\mathrm{CENP}-\mathrm{A}}$ dilution during replication [68]. The deposition of CenH3 $3^{\text {CENP-A }}$ specifically at centromere (in the centric region) plays a crucial role in chromosome segregation by enabling kinetochore formation in mitosis $[69,70]$. This critical need is illustrated in $\mathrm{KO}$ mice which are not able to develop beyond the stage E8.5 [71]. The embryos accumulate mitotic problems, further arguing for a major function of this variant in chromosome segregation.

\subsection{Histone H3-H4 Chaperones}

\subsubsection{Histone Chaperone Definition}

In the NCP, the basic charge of the histones is neutralized by the phosphate backbone of the DNA. Before incorporation into chromatin or after eviction, free histone in solution could potentially, due to their charge, engage into promiscuous interactions with any acidic partner and even could form aggregates in the cell. This is prevented by dedicated proteins, named histone chaperones which escort non-nucleosomal histones in the cell throughout all their cellular life [72]. Some of them directly buffer the positive charge. Nucleoplasmin, the most prominent protein in X.laevis oocyte, thanks to its properties to promote chromatin assembly, was the first protein named "histone chaperone" in 1977 by Laskey [73]. The current definition of a histone 
chaperone is "a protein that associates with histones and is involved in their transfer but is not necessarily part of the final product" [74]. This definition fully illustrates the general property of a histone chaperone, and underlines the fact that in vivo, histones are never left alone from their synthesis to their delivery into or eviction from chromatin. All processes involving histone transfer or modification will thus involve at least one histone chaperone. They have a wide range of functions including histone transport, buffering, storage, histone modification, recycling and deposition onto DNA as well as nucleosome remodeling. In vitro, all histone chaperones share the fundamental ability to promote a progressive transfer of purified histones onto naked DNA at physiological ionic strength to reconstitute nucleosomes from purified components [75]. Interestingly, no single feature in term of sequence allows to demarcate a protein as a histone chaperone and some proteins turned out to function as histone chaperones after having been first characterized for other functions. Among histone chaperones, we can consider a first category according to affinity for either $\mathrm{H} 2 \mathrm{~A}-\mathrm{H} 2 \mathrm{~B}$ or $\mathrm{H} 3-\mathrm{H} 4$. Then, within these categories, a further distinction depends on the selectivity for replicative histones and/or for one or several particular histone variants. Here, we focus on $\mathrm{H} 3-\mathrm{H} 4$ chaperones with an emphasis on those involved in histone deposition using newly synthesized histones (new/de novo deposition) or old histones (recycling) (Table 2.1) (for reviews on histone chaperones [24,76,77]).

\subsubsection{Dedicated H3-H4 Chaperones}

\subsubsection{H3.1/2-H4 Chaperone}

The chromatin assembly factor $1(\mathrm{CAF}-1)$ is the unique histone chaperone complex that interacts selectively with the replicative variants $\mathrm{H} 3.1 / 2$ (Fig. 2.3). The CAF-1 complex was identified in 1989 on the basis of its ability to promote specifically nucleosome assembly in vitro onto newly synthesized DNA during replication with cytosolic extracts derived from human cells [78]. It consists of three distinct subunits p150/CHAF1A , p60/CHAF1B and p48/RbAp48/RBBP4 also referred to as "large", "mid" and "small" subunits. They are functionally conserved in S.cerevisiae as CAC1, CAC2 and CAC3, respectively. The "large" subunit, p150, provides a 
scaffold for the other CAF-1 subunits and mediates recruitment of the complex and interaction with other nuclear factors. In particular, its N-terminal portion contains two important regions: a stretch that is enriched in K/E/R amino acids (KER) predicted to bind DNA, and a proliferating cell nuclear antigen (PCNA) interacting peptide (PIP-box) motif $[79,80]$. An oscillation between monomeric and homo-oligomeric forms of p150 participates in the regulation of the functional activity of CAF-1 $[81,82]$. In addition to histone binding, p150 interacts with heterochromatin protein 1 (HP1), an interaction of importance for the replication of pericentric heterochromatin $[83,84]$.The "mid" subunit, p60, with a WD40 propeller fold involved in the binding of $\mathrm{H} 3-\mathrm{H} 4$ dimer, is responsible for histone loading. The "small" subunit, p48, provides less-well characterized accessory interactions and is part of several other chromatin regulating complexes such as the corepressor mSin3A [85]. It can possibly serve as an interface or link between various complexes. The H3.1 complex purified from human cell extracts retrieved all three CAF1 subunits required for the deposition of $\mathrm{H} 3.1$ onto DNA coupled with DNA synthesis [86] as found later with the H3.2 complex purification [40]. Thus, the deposition of both $\mathrm{H} 3$ replicative histones relies on CAF-1. The current model for histone deposition promoted by CAF-1 involves that the complex binds an $\mathrm{H} 3-\mathrm{H} 4$ dimer and that a transient association of two CAF-1-H3-H4 allows two histone chaperone complexes to concertedly deposit one $(\mathrm{H} 3-\mathrm{H} 4)_{2}$ tetramer onto DNA [87]. Loss of p150 CAF-1 in homozygous mutants leads to very early developmental arrest at the 16-cell stage in mice (between stages E2.0 and E3.0). These embryos show severe alterations in the organization of cell nuclei and their constitutive heterochromatin [88]. In ES cells, downregulation of CAF-1 can favor the emergence of cells showing properties of totipotent cells [89]. In somatic cells, induction to pluripotency IPS cells is facilitated when CAF-1 is reduced [90]. In T cells, CAF-1 cooperate with DNA methyltransferases and histone modifying enzymes to maintain silent states of the Cd4 gene [91]. This is in line with the general view according to which CAF-1 can contribute to the maintenance of somatic cell identity by stabilizing chromatin patterns [11]. 


\subsubsection{H3.3-H4 Chaperones}

H3.3 variants present two selective H3.3 histone chaperones: the Histone regulator A (HIRA) complex and death domain-associated protein 6 - $\alpha$-thalassaemia/mental retardation syndrome X-linked (DAXX-ATRX) (for review [92,93]) (Fig. 2.3).

The HIRA gene was identified in 1995 within a region of chromosome 22q11.2 deleted in most patients with a developmental disorder, the DiGeorge syndrome [94]. The HIRA acronym comes from its amino acid sequence homology to the two S. cerevisiae proteins histone regulation 1 and 2 (Hir1p and Hir2p). Initially described as a chaperone involved in a DSI nucleosome assembly pathway using the $X$. laevis egg extract model system [95], the identification of HIRA in the purifed H3.3 complex revealed its dedicated function in the deposition of H3.3 [86]. In addition to HIRA, two other proteins, ubinuclein 1 (UBN1) and calcineurin-binding protein 1 (CABIN1), co-purified with H3.3 and turned out later to be part of the HIRA histone chaperone complex $[96,97]$. Both UBN1 and CABIN1 interact with HIRA which plays therefore a central platform role in the complex. UBN1, first identified as a nuclear protein interacting with cellular and viral transcription factors [98], is the subunit that directly interacts with the H3.3-H4 dimer [99]. X-ray crystallographic analysis, revealed that the Hpc2-related domain (HRD) in UBN1 binds H3.3 in the proximity of the three residues AIG at positions 87-8990 (in the $\alpha 2$ helix of the histone fold domain) that are different between $\mathrm{H} 3.1 / 2$ and $\mathrm{H} 3.3$ [100]. The Gly90 in H3.3 mediates the specificity for binding to H3.3-H4 over H3.1-H4. CABIN1 was first described as a corepressor of the MEF2 family of transcription factors [101]. To date, its exact function within the HIRA complex remains unclear. Like HIRA, UBN1 and CABIN1 have S. cerevisiae counterparts, histone periodic control $2(\mathrm{Hpc} 2 \mathrm{p})$ and histone regulation 3 (Hir3p), respectively. They form with Hir1p and Hir2p, the Hir complex which is involved in the incorporation of $\mathrm{H} 3$ independently of DNA synthesis in yeast [102]. The HIRA subunit forms a homotrimer that interacts with two CABIN1 subunits [103]. This trimeric structure is required for the functional activity of the HIRA complex in depositing H3.3. Ubinuclein 2 (UBN2), which is a 
paralog of UBN1 that interacts with HIRA [96], forms with HIRA another complex which appears distinct from the one comprising UBN1 [104]. These two complexes could cooperatively deposit H3.3 onto cis-regulatory regions in mouse embryonic stem cells (mESCs). While yeast exhibits a single Hpc2, understanding why other eukaryotes evolved with the emergence of two UBN paralogs will be interesting to explore. In a manner that compares with $\mathrm{H} 3.3 \mathrm{KO}, \mathrm{HIRA}$ is required for proper development in vertebrates, possibly reflecting their tight functional connexion. HIRA KO mice die by stage E10.0 or E11.0 as a consequence of abnormal gastrulation [105].

DAXX was originally described as a Fas death receptor binding protein that induced apoptosis via JNK pathway activation [106]. ATRX was identified through the discovery of mutations in the corresponding gene in a form of X-linked mental retardation (ATR-X syndrome) in young males $[107,108]$. It is a member of the SNF2 family of chromatin remodeling factors [109]. Chromatin remodelers consist of a group of protein complexes containing an ATPase subunit that regulate a number of DNA transactions by sliding, removing and reconstructing nucleosomes [110]. The discovery of DAXX and ATRX in complex with H3.3 suggested a role for these two proteins in the deposition of this variant $[55,56]$. Although DAXX and ATRX along with HIRA associate with $\mathrm{H} 3.3$, they form distinct $\mathrm{H} 3.3$ complexes [111]. Interestingly, in contrast to HIRA, DAXX and ATRX have no known counterparts in budding yeast suggesting a more recent function for this complex possibly in metazoans. In the DAXX-ATRX-H3.3 complex, DAXX is the component that interacts directly with H3.3 while ATRX allows the targeting to heterochromatin [112]. The crystal structure of the histone-binding domain of DAXX bound to the H3.3-H4 dimer revealed the principal determinants of human H3.3 specificity with Ala87 and Gly90 in H3.3. DAXX prefers Gly90 in H3.3 over the hydrophobic Met90 in H3.1 [113,114]. As mentioned above, the UBN1 subunit in the HIRA complex has nearly identical points of contact in the proximity of $\mathrm{H} 3.3 \mathrm{G} 90$ although the mechanism for $\mathrm{H} 3.3 \mathrm{G} 90$ recognition are likely distinct [100]. Of note, in human cells overexpressing CenH3 ${ }^{\text {CENP-A }}$ the strict selectivity of DAXX-ATRX 
for H3.3 is altered and DAXX binds the centromeric CenH3 ${ }^{\text {CENP-A }}$ leading to its mis-localization. This occurs at sites of active histone turnover and involves an unusual heterotypic tetramer containing CenH3 ${ }^{\text {CENP-A }}-\mathrm{H} 4$ with H3.3-H4 [66,115-118]. In addition, DAXX can function independently of ATRX to repress endogenous retroviruses, in a process that does not involve H3.3 incorporation into chromatin [119]. Both loss of DAXX and ATRX are embryonic lethal in mice at stage E9.5 $[120,121]$. ATRX KO cells exhibit loss of the H3K9me3 heterochromatin modification, loss of repression and aberrant allelic expression arguing for a role of ATRX in the maintenance of silencing memory at imprinted loci [122].

\subsubsection{CenH3 ${ }^{\text {CENP-A }-H 4 ~ C h a p e r o n e ~}$}

The histone chaperone dedicated to the centromeric histone $\mathrm{H} 3$ variant $\mathrm{CenH} 3^{\mathrm{CENP}-\mathrm{A}}$ is the Holliday junction recognition protein (HJURP) (for review [69]) (Fig. 2.3). Described in 2007 as a protein that binds Holliday junction, HJURP was initially involved in the homologous recombination (HR) pathway in the double strand break (DSB) repair mechanism [123]. As for CAF-1, HIRA and DAXX-ATRX, the biochemical purification of the protein complex associated with CenH3 $3^{\text {CENP-A }}$ in human cells enabled to identify HJURP as a CenH3 ${ }^{\text {CENP-A }}$ histone chaperone $[124,125]$. The yeast suppressor of chromosome mis-segregation 3 (Scm3) stands as the HJURP counterpart in S. Cerevisiae. Despite their conserved function in CenH3 deposition, HJURP/Scm3 homologues exhibit high degrees of sequence divergence among species likely as a consequence of the rapid co-evolution of the chaperone and the variant. The selectivity of HJURP for CenH3 ${ }^{\text {CENP-A }}$ is mediated by the interaction of its CENP-A binding domain (CBD) in the N-terminal part of the protein with the CENP-A targeting domain (CATD) in CenH3 ${ }^{\text {CENP-A }}$ (composed of the $\alpha 2$ helix and the loop L1) [126]. Structural analysis showed that the CBD of HJURP binds a CenH3 ${ }^{\text {CENP-A }}{ }_{-}$44 dimer [127]. The homodimerization of HJURP, through its HJURP C-terminal domain 2 (HCTD2), is required for CenH3 ${ }^{\text {CENP-A }}$ deposition, leading to the hypothesis that HJURP dimerization allows to bring two CenH $3^{\mathrm{CENP}-\mathrm{A}}-\mathrm{H} 4$ dimers to form the $\left(\mathrm{CenH} 3^{\mathrm{CENP}-\mathrm{A}}-\mathrm{H} 4\right)_{2}$ tetramer at centromeric DNA [128]. Of note, in addition to its role as 
chaperone of CenH3 ${ }^{\text {CENP-A }}$, HJURP also interacts and recruits CENP-C, another kinetochore component, at centromere [129].

\subsubsection{Other H3-H4 Chaperones}

Other $\mathrm{H} 3-\mathrm{H} 4$ chaperones, less selective, bind several $\mathrm{H} 3$ histones (both replicative and variants) and participate in the nucleosome assembly line. Upstream or downstream the new deposition process, they can be involved in handling soluble new histones or in recycling nucleosomal histones or both.

The anti-silencing function 1 (ASF1) histone chaperone was initially identified in S. cerevisiae in a screen for silencing defects upon overexpression [130]. ASF1 was the first histone chaperone crystallized in complex with $\mathrm{H} 3-\mathrm{H} 4[131,132]$. Its domain interacting with histones contains an Ig-like fold that binds the $\alpha 2-\alpha 3$ helices of histone H3. Together with CAF-1, ASF1 facilitates chromatin assembly linked to DNA synthesis in vitro [133,134]. However, ASF1 is not directly involved in the deposition mechanism but likely acts by transferring $\mathrm{H} 3-\mathrm{H} 4$ dimers to the downstream histone chaperones that are depositing the new histones $\mathrm{H} 3-\mathrm{H} 4$. In mammals, two paralogous proteins exist, ASF1a and ASF1b with distinct cellular roles [135]. ASF1a and ASF1b co-purified with H3.1 and H3.3 complexes arguing for their role in both DSC and DSI assembly lines [86]. Although ASF1a and ASF1b do not exhibit preferences for H3.1/2 or H3.3 per se and can associate with both $\mathrm{H} 3.1 / 2-\mathrm{H} 4$ and $\mathrm{H} 3.3-\mathrm{H} 4$ dimers, ASF1a harbors a preference for the HIRA complex whereas ASF1b interacts preferentially with CAF-1 [136]. ASF1a and ASF1b bind a motif named $B$ domain which is present in both HIRA and CAF-1p60 subunits but how the interaction preferences are achieved is not fully understood [137]. Importantly, ASF1 a and $b$ interact with the $\mathrm{B}$ domain of CAF-1p60 or HIRA through a conserved hydrophobic groove at a site opposite to that of their interaction with $\mathrm{H} 3-\mathrm{H} 4$. A ternary complex (CAF-1-ASF1-H3.1H4) or (HIRA-ASF1-H3.3-H4) could thus represent an intermediate that enables histones to be handed over from one chaperone to the next. ASF1a and b bind $\mathrm{H} 3-\mathrm{H} 4$ at the tetramerization interface and therefore sterically prevent their tetramerization $[131,132,138]$. Furthermore, these 
chaperones are able to disrupt an $(\mathrm{H} 3-\mathrm{H} 4)_{2}$ tetramer into two $\mathrm{H} 3-\mathrm{H} 4$ dimers but alone cannot disengage it from DNA. Notably, in addition to participating upstream in the new deposition, ASF1 $\mathrm{a}$ and $\mathrm{b}$ are also involved in old/pre-existing/parental histones recycling during replication in association with mini chromosome maintenance 2 (MCM2) [139,140].

MCM2 is a subunit of the Cdc45-MCM(2-7)-GINS (CMG) replicative helicase that unwinds DNA and separates the two strands of the double helix prior to the action of DNA polymerases [141]. Although its binding capacity to histones was discovered almost 20 years ago [142], its central role in handling both old and newly synthesized histones during replication was highlighted more recently [139]. Together with other subunits of the helicase (MCM3-7), MCM2 coimmunoprecipitates with $\mathrm{H} 3-\mathrm{H} 4$, enriched in parental histones, from nuclear extracts in S phase human cells. In contrast, only MCM2 co-immunoprecipitates with newly synthesized histones $\mathrm{H} 3-\mathrm{H} 4$ and with ASF1a and $\mathrm{b}$ in human cytosolic cells extracts. This suggests that independently from its role at the replication fork, MCM2 could also play a specific role as a histone chaperone. Biochemical studies revealed that the $\mathrm{N}$-terminal tail of $\mathrm{MCM} 2$, containing the histone-binding domain (HBD), directly binds histone H3 in vitro [143]. Then, structural analysis showed that MCM2 HBD can bind both an $(\mathrm{H} 3-\mathrm{H} 4)_{2}$ tetramer and a dimer of $\mathrm{H} 3-\mathrm{H} 4$ engaged in an interaction with the other chaperone ASF1 [144,145]. The interaction of MCM2 with histones involving a tetramer-to-dimer transition would be important for the proper dynamics of histones during passage of the replication fork. Moreover, the finding that MCM2 can bind all H3 (H3.1, H3.2, H3.3 and CENP-A) [144] suggests that this mechanism to handle histones could apply throughout the entire genome [146].

POLE3 and POLE4 are accessory subunits of the mammalian Pole, the polymerase that is active on the leading strand at the replication fork [147]. A recent study discovered that the human POLE3-POLE4 complex binds to histones $\mathrm{H} 3-\mathrm{H} 4$ (either $\mathrm{H} 3.1$ or $\mathrm{H} 3.3$ ) as dimer or tetramer [148]. POLE3-POLE4 binds $\mathrm{H} 3-\mathrm{H} 4$ in the context of chromatin during replication excluding the possibility that it chaperones soluble histones. Moreover, POLE3-POLE4 
associates with histones carrying modifications characteristic of both newly synthesized and parental histones suggesting that POLE3-POLE4 may handle both new and old histones in proximity of the leading strand. Another recent study in S.cerevisiae showed that the yeast counterparts Dpb3 and Dpb4, drive the recycling of parental histones onto the leading strand, indicating that their function in histone dynamics at replication fork is likely conserved [149]. We will discuss later how the dynamics of recycling and deposition of histones respectively on the leading and lagging strand has combined all these features.

\subsection{Deposition of H3-H4 Histones onto DNA}

During most of DNA processes such as replication, repair or transcription, the nucleosome organization is disassembled then reassembled. The disassembly is generally required to permit access of the actors of the different machineries to DNA and the reassembly is needed to maintain the chromatin organization to ensure genome integrity. During the reassembly, deposition of both new and old/pre-existing/parental histones occurs. Recycling of old histones contributes to preserve positional information and allows variants and PTMs transmission while new histones deposition could give rise to epigenome fluctuations. The mechanisms of new histone deposition involving histone chaperones have been explored over the last 25 years while those involved in the deposition/recycling of old histones were under investigations more recently. Of note, the studies on histone dynamics in vivo benefited in particular from the SNAPtag technology which allows to visualize selectively either newly synthesized or old histones in the cell $[68,150]$.

\subsubsection{Deposition of New H3-H4 Histones}

\subsubsection{New H3.1/2-H4 Deposition by CAF-1}

The histone chaperone CAF-1 deposits new replicative histones at sites of DNA synthesis both during replication when DNA is duplicated and during repair when DNA damage is repaired [78,151] (Fig. 2.4). Thus, CAF-1 deposits new H3.1/2 onto DNA in a DSC manner both coupled 
to replication during S phase and independently of replication at sites of DNA repair throughout interphase $[103,41]$. CAF-1 is recruited to sites of DNA synthesis mainly by the interaction of its large subunit p150 with the DNA sliding clamp, PCNA $[79,80]$. The phosphorylation of CAF-1 p150 by Cdc7/Dbf4 during S phase promotes this interaction by regulating the homooligomerization status of p150 [81]. The p60 subunit is also a substrate for phosphorylation by cdk in vitro, which may represent another mechanism by which CAF-1 deposition activity is regulated $[152,153]$. The SNAP-technology enabled to follow the deposition of newly synthesized H3.1 in the cell. H3.1 new deposition colocalized with replication sites during S phase and CAF-1 depletion abrogated this new H3.1 deposition [39]. To date, no other histone chaperone proved able to deposit H3.1 in the absence of CAF-1. However, H3.3 deposition promoted by HIRA does occur at replication sites when CAF-1 is depleted [39]. These findings suggest that, when the assembly coupled to DNA synthesis is defective, the gaps left free could be filled up via in a compensatory mechanism involving the DSI nucleosome assembly pathway in order to maintain chromatin integrity.

\subsubsection{New H3.3-H4 Deposition by HIRA}

The HIRA complex is involved in the DSI deposition of new H3.3 histone variant (Fig. 2.4) and this new deposition occurs throughout interphase as visualized in the cell by using the SNAP-tag technology [39]. H3.3 is enriched in the body of transcribed genes, at promoter regions at both active and inactive genes and also at genic and intergenic regulatory regions [55]. Thus, HIRAdependent enrichment of $\mathrm{H} 3.3$ in the coding regions of genes appears mainly associated with active transcription. The deposition of H3.3 at transcribed genes was underscored by the coimmunoprecipitation of the HIRA complex with both the initiating and elongating forms of the RNA pol II harboring specific phosphorylation at serine 5 and serine 2 into its carboxy terminal domain (CTD), respectively [39]. The interactions between the HIRA complex and several actors of the transcriptional process further support the link between HIRA-dependent H3.3 deposition and transcription [154-156]. Furthermore, post-translational modifications of the HIRA subunit 
can modulate the H3.3 deposition activity of the complex $[157,158]$.

The HIRA complex can also promote deposition of H3.3 independently of transcription in several circumstances, at UV damage sites where H3.3 deposition occurs upon detection of the DNA damage prior to repair [159], at fertilization in paternal chromatin before the first round of DNA replication [52,53] and onto viral DNA upon virus infection. In this latter case, depending of the system, H3.3 accumulation onto viral DNA correlated with active or repress viral transcription and with virus latency [160-162].

The HIRA complex shows unique DNA binding properties as compared to other $\mathrm{H} 3-\mathrm{H} 4$ histone chaperones, and its depletion increases DNA sensitivity to nucleases [39]. The HIRA complex from cell extracts binds to both double-stranded and single-stranded DNA suggesting that it could recognize particular DNA structures [103]. The ability of the HIRA complex to bind naked DNA provides a mechanism of new H3.3 deposition that may operate to avoid nucleosome-free DNA regions which could be deleterious for maintenance of chromatin organization and genome integrity. This leads to the proposal of a nucleosome gap filling mechanism for the HIRA-dependent $\mathrm{H} 3.3$ deposition and a crucial role to maintain chromatin integrity $[39,163]$.

\subsubsection{New H3.3-H4 Deposition by DAXX-ATRX}

The histone chaperone DAXX-ATRX is responsible for the enrichment of H3.3 in heterochromatin at pericentric regions and telomeres [55,56]. Although not formally demonstrated, DAXX-ATRX is assumed to be key for the deposition of new histone variant H3.3 at these heterochromatic regions in a DSI manner (Fig. 2.4). Whether the deposition of H3.3 by DAXX-ATRX at these specific locations occurs during a particular time window during the cell cycle and whether it does link to the deposition of $\mathrm{H} 2 \mathrm{AZ}$ variant will be interesting to explore [164]. While DAXX directly interacts with H3.3 [113,114], ATRX recognizes H3K9me3 through its ATRX-Dnmt3-Dnmt3L (ADD) domain and could therefore target DAXX to these locations [112]. DAXX-ATRX also mediates H3.3 deposition at G-quadruplexes (G4) and at endogenous 
retroviruses through a possible direct binding of ATRX to these structures and transposable elements $[165,166]$. These data have led to propose a role for ATRX in suppressing recombination at telomeric repeats by resolving $\mathrm{G} 4$ structures through the deposition of $\mathrm{H} 3.3$ [167]. At transposable elements, the incorporation of $\mathrm{H} 3.3$ is proposed to silence repetitive elements through regulation of H3K9me3 $[168,166]$.

DAXX-ATRX also mediates H3.3 enrichment outside of heterochromatin and repetitive elements. DAXX-ATRX together with the HIRA complex was proposed to induce virus latency by enabling H3.3 accumulation onto viral DNA [160]. In the nervous system, the serine residue 669 of DAXX is phosphorylated by the homeodomain-interacting protein kinase 1 (HIPK1) and upon neuronal activation, the calcium-dependent phosphatase calcineurin $(\mathrm{CaN})$ dephosphorylates S669 [169]. This dephosphorylation, by enhancing DAXX activity, increased H3.3 enrichment at promoters and enhancers of immediate early genes leading to their active transcription. However, a major role for the H3.3-mediated activity of DAXX-ATRX is likely linked to its impact on heterochomatin function as shown above.

\subsubsection{New CenH3 ${ }^{\text {CENP-A }-H 4 ~ D e p o s i t i o n ~ b y ~ H J U R P ~}$}

The histone chaperone HJURP deposits the new histone variant CenH3 ${ }^{\text {CENP-A }}$ at centromere in a DSI manner during late mitosis (telophase)/early G1 in mammals (Fig. 2.4) [68,124,125]. HJURP localizes to centromeres at the time of CenH3 ${ }^{\text {CENP-A }}$ deposition and CDK kinases control its timely recruitment to centromeres in late mitosis by changing its phosphorylation status $[170,171]$. HJURP interacts with DNA through a specialized domain, which is essential to deposit CenH3 ${ }^{\text {CENP-A }}$ at centromeres, highlighting that HJURP is not merely escorting CenH3 ${ }^{\text {CENP-A }}$, but plays an active part in CenH3 ${ }^{\text {CENP-A }}$ deposition [170]. Of note, although HJURP is the histone chaperone involved in the final step of $\mathrm{CenH} 3^{\mathrm{CENP}-\mathrm{A}}$ deposition, numbers of other factors are required for the proper incorporation of this histone variant into centromere (review [69]). CenH3 ${ }^{\text {CENP-A }}$ post-translational modifications are important for its deposition. Ser68 phosphorylation of CenH3 ${ }^{\text {CENP-A }}$ prevents an interaction with HJURP in the pre-deposition 
complex, helping to prevent premature loading [172]. The crystal structure at the interface of CenH $3^{\text {CENP-A }}$ and HJURP shows that Ser68 lies in the histone variant binding domain of HJURP. Moreover, Lys124 ubiquitylation of $\mathrm{CenH} 3^{\mathrm{CENP}-\mathrm{A}}$ plays a role in $\mathrm{CenH} 3^{\mathrm{CENP}-\mathrm{A}}$ deposition by controlling the stability of the CenH3 $3^{\mathrm{CENPA}}-\mathrm{HJURP}$ complex through a regulatory mechanism involving the cullin 4 (CUL4) ubiquitin ligase [173]. The new deposition of CenH3 ${ }^{\mathrm{CENP}-\mathrm{A}}$ only occurs in late mitosis/early $\mathrm{G} 1$ phases, thus $\mathrm{CenH} 3^{\mathrm{CENP}-\mathrm{A}}$ is diluted during $\mathrm{S}$ phase and distributed evenly to both daughter chromosomes in mammals [68]. In addition to deposit new CenH3 $3^{\text {CENP-A }}$, HJURP may be also required for its retention during $S$ phase. By interacting with the replicative helicase complex, HJURP is proposed to retain and recycle CenH3 ${ }^{\mathrm{CENP}-\mathrm{A}}$ following DNA replication [174]. During S phase, new deposition of both H3.1 (in a DSC manner) and H3.3 (through a possible post-replicative gap-filling mechanism) is observed, filling the gaps generated by diluting CenH3 ${ }^{\mathrm{CENP}-\mathrm{A}}$. Interestingly, the detected loss of $\mathrm{H} 3.3$ only later in $\mathrm{G} 1$ phase argues that $\mathrm{H} 3.3$ variant could serve as a CenH3 ${ }^{\mathrm{CENP}-\mathrm{A}}$ placeholder [175].

\subsubsection{Recycling of Old H3-H4 Histones}

Chromatin integrity is critical for cell function and identity but is challenged by DNA processes that involve nucleosome disassembly. How chromatin architecture and the information that it conveys are preserved? For example, during replication, the chromatin structure is affected by the transient disruption of histone-DNA interaction from old/pre-existing/parental nucleosomes located ahead of replication forks (Disassembly). Chromatin assembly onto daughter strands relies on two distinct processes: the transfer of old histones (Recycling) and second the deposition of new histones (New deposition). The latter process, as mentioned before is regulated by the CAF-1 complex that deposits new $\mathrm{H} 3.1 / 2-\mathrm{H} 4$ histones onto both daughter strands. Experiments in the 1980s with bulk chromatin demonstrated the retention of parental histones on daughter strands $[176,177]$. The recycling of old histones with their PTMs and the subsequent modifications of new histones to mirror the parental ones would participate in the maintenance of chromatin identity. The transmission of parental PTMs during replication 
appears to occur in human cells [178] This is critical for features to be inherited from one cell to the next.

ASF1 has been the first $\mathrm{H} 3-\mathrm{H} 4$ chaperone implicated in the recycling of old histones during replication [139]. ASF1 was proposed to handle old histones at replication fork via an ASF1-(H3-H4)-MCM2-7 intermediate. An important role for MCM2 emerged based on structural analysis showing that MCM2, in contrast to ASF1, can bind an $(\mathrm{H} 3-\mathrm{H} 4)_{2}$ tetramer $[144,145]$. This mode of binding implies that, once evicted from DNA possibly by the force of the helicase and the activity of remodelling factors, nucleosomal $\mathrm{H} 3-\mathrm{H} 4$ could be directly transferred to $\mathrm{MCM} 2$ as a tetramer. After this step old tetrameric $(\mathrm{H} 3-\mathrm{H} 4)_{2}$ could simply be directly loaded onto the newly synthesized DNA. Alternatively, old $\mathrm{H} 3-\mathrm{H} 4$ could be deposited as dimers after splitting by ASF1 [146]. Although reassociation of the two parental dimer partners might be favored most of the time, mixing $\mathrm{H} 3.3-\mathrm{H} 4$ dimers, but not $\mathrm{H} 3.1-\mathrm{H} 4$ dimers, was reported with potential important role in the inheritance of epigenetic traits $[179,180]$.

During replication, the two daughter chromatids differ in how they are replicated. The leading strand synthesis occurs in the direction of the fork progression while the lagging strand proceeds in interspersed segments in an opposite direction. Recycling old histones on leading and lagging strands exploit distinct mechanisms involving histones chaperones. In yeast, while MCM2 operates on the lagging strand, Dpb3-Dpb4 subunits of the polymerase $\varepsilon$ act on the leading strand $[149,181]$. The function of MCM2 in recycling old histones onto the lagging strand is conserved in human [182]. POLE3-POLE4, the human counterpart of Dpb3-Dpb4, recently described as a H3-H4 chaperone whose depletion affects chromatin at replication fork, could similarly participate in the recycling of old histones onto the leading strand in human [148]. Whether, the evicted $(\mathrm{H} 3-\mathrm{H} 4)_{2}$ tetramer splits in to dimers before recycling/deposition onto the leading strand remains to be explored, in particular in light of possible connection with Asf1. A scheme of the current model for histone dynamics at replication fork, involving old histone recycling and new histone deposition, is shown in Fig. 2.5. 
Of note in yeast, Cohesion establishment factor 4 (Ctf4), a replisome factor that links the CMG helicase on the leading strand to the DNA polymerase $\alpha$ on the lagging strand (through a direct interaction with both GINS and pol $\alpha$ ) [183], participates in the recycling of old histones on this latter strand [181]. Ctf4 and its human counterpart, Acidic nucleoplasmic DNA binding protein-1 (And-1), form homotrimers that exhibit homology with the homo-trimeric form of the HIRA subunit of the histone chaperone complex HIRA [103]. This intriguing homology could suggest for Ctf4/And-1 and HIRA a similar way of mediating protein and DNA interactions at particular bubble DNA structures as encountered at replication fork for Ctf4/And-1 and perhaps at transcription sites for HIRA.

The existence of distinct mechanisms for recycling old histones on the two daughter strands raises new interesting hypothesis [184]. Indeed, while ensuring an equal partitioning of old histones for most cells, it may as well offer an opportunity for unequal partitioning. For example, in Drosophila male germline and adult midgut, replicative $\mathrm{H} 3$ and $\mathrm{CenH} 3^{\mathrm{CENP}-\mathrm{A}}$ are asymmetrically distributed, respectively. The daughter stem cell retains the parental/old histones while the post-mitotic differentiating daughter cell genome is assembled with new histones $[185,186]$. The existence of distinct mechanisms to recycle old histones might be a way to regulate asymmetric distribution of old histones onto the two daughter cells in the wake of the replication. This could be crucial to initiate a differentiation program by loosing parental marks.

\subsection{Concluding Remarks and perspectives}

Chromatin can protect DNA from various deleterious threats while remaining flexible to enable the regulation of gene expression and programmed changes in cell identity to occur during normal development. The histone $\mathrm{H} 3$ family and its various chaperones are crucial for allowing dynamic accessibility to particular genomic loci. Over recent decades, much progress has been made in the study of histones and their modes of incorporation into chromatin. This is 
particularly true for histones $\mathrm{H} 3-\mathrm{H} 4$ with the identification of histone chaperones that are often specialized in the deposition of one peculiar $\mathrm{H} 3$ variant at a particular time and at specific locations onto the genome. We are unveiling complete histone $\mathrm{H} 3$ deposition pathways from their site of synthesis to their sites of delivery and we are also now currently elucidating how old histones are recycled at replication fork. Open questions remain regarding this network of histones and histone chaperones. For example, histone $\mathrm{H} 3$ chaperones are most often protein complexes whose stoichiometry, post-translational modifications and functional regulations are still poorly characterized and understanding how they may link to cell cycle control and cell fate will be extremely exciting. While the deposition process of $\mathrm{H} 3-\mathrm{H} 4$ is now rather well understood, the mechanisms and histone chaperones involved in the deposition of $\mathrm{H} 2 \mathrm{~A}-\mathrm{H} 2 \mathrm{~B}$ dimers still needs to be deepened. Processes of old histone recycling started recently to be deciphered at replication fork but old histone recycling also occurs at DNA repair and transcription sites $[187,188]$. Most fascinating is to understand how the marking with particular variants actually experience cell division and can be restored after the passage of the replication fork. Elucidating therefore the mechanisms that operate during repair and transcription would also be crucial. Furthermore, exploring how this network of histones and histone chaperones is potentially rewired when one of several of the actors are mutated or deregulated in particular during cancer will bring undoubtedly important new findings in the field. 


\section{Figure Legends}

Fig. 2.1: Differences between replicative histones $(\mathrm{H} 3.1$ and $\mathrm{H} 3.2)$ and histone variants $(\mathrm{H} 3.3$ and $\mathrm{CenH} 3^{\mathrm{CENP}-\mathrm{A}}$ ) in human. Replicative histone genes are organized in clusters and lack introns whereas histone variants are encoded by single genes (two for $\mathrm{H} 3.3$ and one for $\mathrm{CenH} 3^{\mathrm{CENP}-\mathrm{A}}$ ) and have introns. While $\mathrm{H} 3.3 \mathrm{~A}$ and $\mathrm{H} 3.3 \mathrm{~B}$ genes encode the same protein, their architecture is different. In particular, their promoter regions contain distinct putative binding sites for transcriptional regulators. Transcripts of replicative histones do not undergo polyadenylation and harbor a 3' stem-loop structure while transcripts of histone variants are polyadenylated and processed through splicing like most RNA pol II mRNAs. Replicative histone genes are highly transcribed during $S$ phase which is not the case of histone variant genes that can be transcribed with various timings depending of the variant (throughout the cell cycle for $\mathrm{H} 3.3$ and during $\mathrm{G} 2 / \mathrm{M}$ phases for $\mathrm{CenH} 3^{\mathrm{CENP}-\mathrm{A}}$ ) .

Fig. 2.2: (A) Alignment of human amino acid sequences corresponding to the replicative histones $\mathrm{H} 3.1$ and $\mathrm{H} 3.2$ and the histone variants $\mathrm{H} 3.3$ and $\mathrm{CenH} 3^{\mathrm{CENP}-\mathrm{A}}$. Sequences are compared to $\mathrm{H} 3.1$ and the residue differences are highlighted. $\mathrm{H} 3.1$ and $\mathrm{H} 3.2$ differ by only one residue at position $96 . \mathrm{H} 3.3$ differs from $\mathrm{H} 3.1$ by five residues (at positions $31,87,89,90$ and 96) and from H3.2 by four residues (at positions 31, 87, 89 and 90 ), while the amino acid sequence of $\mathrm{CenH}_{3}{ }^{\mathrm{CENP}-\mathrm{A}}$ exhibits less than $50 \%$ identity with $\mathrm{H} 3.1$. The histone fold domain containing three $\alpha$-helices and two loops is shown. (B) Crystal structures of H3.1, H3.3 and CenH3 ${ }^{\text {CENP-A }}$ nucleosome core particles (NCP). The NCP contains an histone octamer that consists of a tetramer with two $\mathrm{H} 3-\mathrm{H} 4$ dimers $\left((\mathrm{H} 3-\mathrm{H} 4)_{2}\right)$ flanked by two $\mathrm{H} 2 \mathrm{~A}-\mathrm{H} 2 \mathrm{~B}$ dimers. Histone octamer from both H3.1 and H3.3 NCPs is wrapped by 147 bp of DNA [57] whereas 121 bp of DNA wrapped the histone octamer from CenH3 ${ }^{\text {CENP-A }}$ NCP [65]. 
Fig. 2.3: Replicative histones $(\mathrm{H} 3.1$ and $\mathrm{H} 3.2)$ and histone variants $\left(\mathrm{H} 3.3\right.$ and $\left.\mathrm{CenH} 3^{\mathrm{CENP}-\mathrm{A}}\right)$ are de novo deposited onto DNA by their dedicated chaperones using two different nucleosome assembly pathways, DNA synthesis coupled (DSC) and DNA synthesis independent (DSI), respectively. $\mathrm{H} 3.1 / 2-\mathrm{H} 4$ and $\mathrm{CenH} 3^{\mathrm{CENP}-\mathrm{A}}-\mathrm{H} 4$ dimers bind to one histone chaperone, $\mathrm{CAF}-1$ and HJURP, respectively, while $\mathrm{H} 3.3-\mathrm{H} 4$ can associate with two distinct histone chaperones, the HIRA complex and DAXX-ATRX. Of note, the homo-oligomerization status of each component is not indicated and only one molecule is represented.

Fig. 2.4: (A) Enrichment of $\mathrm{H} 3.1, \mathrm{H} 3.3$ and $\mathrm{CenH} 3^{\mathrm{CENP}-\mathrm{A}}$ mediated by their dedicated histone chaperones at specific genomic sites and/or during particular DNA processes in cycling cells. CAF-1 deposits replicative $\mathrm{H} 3.1 / 2-\mathrm{H} 4$ genome wide mainly during replication but also during DNA repair. The HIRA complex deposits $\mathrm{H} 3.3-\mathrm{H} 4$ at active genes, promoters, sites of DNA repair and potentially at any transient nucleosome free region by a gap-filling mechanism, while DAXX-ATRX is involved in the enrichment of H3.3-H4 mainly at heterochromatin (telomere and pericentromere) but also at regularory elements. HJURP mediates the incorporation of CenH3 ${ }^{\text {CENP-A }}-\mathrm{H} 4$ at centromere (in centric heterochromatin). (B) Genomic distribution of H3.1, H3.3 and CenH3 ${ }^{\text {CENP-A }}$ [20] from published ChIP-Seq data in HeLa cells $[140,66]$. The plot shows the enrichment relative to input for all variants at a representative region spanning the centromere and the proximal short and long arms of chromosome 18 (p11.21-q21.1). Enriched regions are highlighted in darker colors, illustrating the partitioning of the genome into chromatin domains associated with specific histone $\mathrm{H} 3$.

Fig. 2.5: Current model of histone dynamics at the replication fork. (A) For each old/parental nucleosome disrupted by the replication fork passage, a H3-H4 tetramer is available (Disassembly). The old H3-H4 histones are recycled on newly synthesized DNA either directly as a tetramer or potentially as two dimers (Recycling). New H3-H4 dimers are deposited onto 
newly synthesized DNA to ensure a full complement of nucleosomes on the nascent DNA (New Deposition). Recycling of old/parental histones and deposition of new histones are thought to occur randomly on both the leading (in orange) and the lagging strand (in green). (B) The mechanisms and the histone chaperones involved in the recycling of old histones on the leading and the lagging strands are distinct. At the replication fork, the CMG (Cdc45-MCM(2-7)-GINS) helicase on the leading strand unwinds the DNA. The homotrimer And-1/Ctf4 links the helicase on the leading strand to the pola on the lagging strand through its interaction with both GINS and pol $\alpha$. While the two accessory subunits of pole (POLE3 and POLE4) mediate the recycling of old $\mathrm{H} 3-\mathrm{H} 4$ histones on the leading strand, the helicase subunit, MCM2, operates on the lagging strand. It is still not fully understood whether $\mathrm{H} 3-\mathrm{H} 4$ are directly recycled as tetramers or whether they split as dimers before deposition or whether both events happen. Moreover, if H3H4 split, whether ASF1 handles the H3-H4 dimers before deposition remains unclear. (C) To fulfill the requirement for nucleosome assembly, deposition of newly synthesized H3.1/2-H4 dimers occurs on both strands by the histone chaperone complex CAF-1 through its interaction with the sliding clamp PCNA. The histone chaperone ASF1 would hand over $\mathrm{H} 3.1 / 2-\mathrm{H} 4$ dimers to CAF-1 before deposition. 
Table 2.1 Histone H3-H4 Chaperones

\begin{tabular}{|c|c|c|c|c|}
\hline Chaperone & $\begin{array}{l}\text { Human } \\
\text { subunit(s) }\end{array}$ & $\begin{array}{l}\text { S.cerevisiae } \\
\text { subunit(s) }\end{array}$ & $\begin{array}{l}\text { Histone } \\
\text { preference(s) in } \\
\text { human }\end{array}$ & Function(s) \\
\hline $\begin{array}{l}\text { CAF-1 } \\
\text { complex }\end{array}$ & $\begin{array}{l}\text { p150 (CHAF-1) } \\
\text { p60 (CHAF-2) } \\
\text { p48 (RbAp48) }\end{array}$ & $\begin{array}{l}\text { cac1 } \\
\text { cac2 } \\
\text { cac3 }\end{array}$ & $\mathrm{H} 3.1 / 2-\mathrm{H} 4$ & $\begin{array}{c}\text { New deposition } \\
\text { DSC }\end{array}$ \\
\hline $\begin{array}{l}\text { HIRA } \\
\text { complex }\end{array}$ & $\begin{array}{l}\text { HIRA } \\
\text { CABIN1 } \\
\text { UBN1 or UBN2 }\end{array}$ & $\begin{array}{l}\text { Hir1p and Hir2p } \\
\text { Hir3p } \\
\text { Hpc2p }\end{array}$ & $\mathrm{H} 3.3-\mathrm{H} 4$ & $\begin{array}{c}\text { New deposition } \\
\text { DSI }\end{array}$ \\
\hline DAXX-ATRX & $\begin{array}{l}\text { DAXX } \\
\text { ATRX }\end{array}$ & NA & $\mathrm{H} 3.3-\mathrm{H} 4$ & $\begin{array}{c}\text { New deposition } \\
\text { DSI }\end{array}$ \\
\hline HJURP & HJURP & Scm3 & CenH3 ${ }^{\text {CENP-A }}$ & $\begin{array}{c}\text { New deposition } \\
\text { DSI } \\
\text { Recycling? }\end{array}$ \\
\hline ASF1 & ASF1a or ASF1b & Asf1 & $\begin{array}{l}\mathrm{H} 3.1 / 2-\mathrm{H} 4 \\
\mathrm{H} 3.3-\mathrm{H} 4 \\
\text { CenH3 } \\
\text { CENP-A }\end{array}$ & $\begin{array}{c}\text { Transit, Buffer, } \\
\text { Handover, } \\
\text { Recycling }\end{array}$ \\
\hline MCM2 & MCM2 & Mcm2 & $\begin{array}{l}\mathrm{H} 3.1 / 2-\mathrm{H} 4 \\
\mathrm{H} 3.3-\mathrm{H} 4 \\
\text { CenH3 } \\
\text { CENP-A }\end{array}$ & Recycling \\
\hline Pole & $\begin{array}{l}\text { POLE3 } \\
\text { POLE4 }\end{array}$ & $\begin{array}{l}\text { Dpb3 } \\
\text { Dpb4 }\end{array}$ & $\mathrm{H} 3-\mathrm{H} 4$ & Recycling \\
\hline
\end{tabular}

Not available (NA); DNA synthesis coupled (DSC); DNA synthesis independent (DSI); Chromatin assembly factor 1 (CAF-1); Histone regulator A (HIRA); Histone regulation (Hir); Histone periodic control 2 (Hpc2p); Death domain-associated protein 6 - $\alpha$-thalassaemia/mental retardation syndrome X-linked (DAXX-ATRX); Holliday junction recognition protein (HJURP); Suppressor of chromosome mis-segregation 3 (Scm3); Anti-silencing function 1 (ASF1); Mini chromosome maintenance 2 (MCM2); DNA polymerase $\varepsilon$ (Pole). 


\section{References}

1. Flemming W (1882) Zellsubstanz, Kern und Zelltheilung. F C W Vogel

2. Oudet $P$, Gross-Bellard M, Chambon P (1975) Electron microscopic and biochemical evidence that chromatin structure is a repeating unit. Cell 4:281-300

3. Kornberg RD (1974) Chromatin structure: a repeating unit of histones and DNA. Science 184:868-871

4. Luger K, Mader AW, Richmond RK, Sargent DF, Richmond TJ (1997) Crystal structure of the nucleosome core particle at 2.8 A resolution. Nature 389:251-260. doi:10.1038/38444

5. Olins AL, Olins DE (1974) Spheroid chromatin units (v bodies). Science 183:330-332

6. Heitz E (1928) Das Heterochromatin der Moose. Jahrbücher für wissenschaftliche Botanik 69:762-818

7. Furlong EEM, Levine M (2018) Developmental enhancers and chromosome topology. Science 361:1341-1345. doi:10.1126/science.aau0320

8. Solovei I, Thanisch K, Feodorova Y (2016) How to rule the nucleus: divide et impera. Current opinion in cell biology 40:47-59. doi:10.1016/j.ceb.2016.02.014

9. Allis CD, Jenuwein T (2016) The molecular hallmarks of epigenetic control. Nature reviews Genetics 17:487-500. doi:10.1038/nrg.2016.59

10. Sitbon D, Podsypanina K, Yadav T, Almouzni G (2017) Shaping Chromatin in the Nucleus:

The Bricks and the Architects. Cold Spring Harbor symposia on quantitative biology 82:1-14. doi:10.1101/sqb.2017.82.033753

11. Yadav T, Quivy JP, Almouzni G (2018) Chromatin plasticity: A versatile landscape that underlies cell fate and identity. Science 361:1332-1336. doi:10.1126/science.aat8950

12. Rowley MJ, Corces VG (2018) Organizational principles of 3D genome architecture. Nature reviews Genetics 19:789-800. doi:10.1038/s41576-018-0060-8

13. Waterborg JH (2012) Evolution of histone H3: emergence of variants and conservation of post-translational modification sites. Biochemistry and cell biology $=$ Biochimie et biologie cellulaire 90:79-95. doi:10.1139/o11-036

14. Arents G, Burlingame RW, Wang BC, Love WE, Moudrianakis EN (1991) The nucleosomal core histone octamer at 3.1 A resolution: a tripartite protein assembly and a left-handed superhelix. Proceedings of the National Academy of Sciences of the United States of America 88:10148-10152

15. Zentner GE, Henikoff S (2013) Regulation of nucleosome dynamics by histone modifications. Nature structural \& molecular biology 20:259-266. doi:10.1038/nsmb.2470

16. Farrelly LA, Thompson RE, Zhao S, Lepack AE, Lyu Y, Bhanu NV, Zhang B, Loh YE, Ramakrishnan A, Vadodaria KC, Heard KJ, Erikson G, Nakadai T, Bastle RM, Lukasak BJ, Zebroski H, 3rd, Alenina N, Bader M, Berton O, Roeder RG, Molina H, Gage FH, Shen L, Garcia BA, Li H, Muir TW, Maze I (2019) Histone serotonylation is a permissive modification that enhances TFIID binding to H3K4me3. Nature 567:535-539. doi:10.1038/s41586-019-1024-7 17. Turner BM (1993) Decoding the nucleosome. Cell 75:5-8

18. Strahl BD, Allis CD (2000) The language of covalent histone modifications. Nature 403:41-45. doi:10.1038/47412

19. Talbert PB, Henikoff S (2010) Histone variants--ancient wrap artists of the epigenome.

Nature reviews Molecular cell biology 11:264-275. doi:nrm2861 [pii]

10.1038/nrm2861

20. Mendiratta S, Gatto A, Almouzni G (2019) Histone supply: Multitiered regulation ensures chromatin dynamics throughout the cell cycle. The Journal of cell biology 218:39-54.

doi:10.1083/jcb.201807179 
21. Marzluff WF, Koreski KP (2017) Birth and Death of Histone mRNAs. Trends in genetics : TIG 33:745-759. doi:10.1016/j.tig.2017.07.014

22. Pandey NB, Marzluff WF (1987) The stem-loop structure at the 3 ' end of histone mRNA is necessary and sufficient for regulation of histone mRNA stability. Molecular and cellular biology 7:4557-4559

23. Franklin SG, Zweidler A (1977) Non-allelic variants of histones $2 a, 2 b$ and 3 in mammals. Nature 266:273-275

24. Gurard-Levin ZA, Quivy JP, Almouzni G (2014) Histone chaperones: assisting histone traffic and nucleosome dynamics. Annu Rev Biochem 83:487-517. doi:10.1146/annurev-biochem060713-035536

25. Filipescu D, Muller S, Almouzni G (2014) Histone H3 variants and their chaperones during development and disease: contributing to epigenetic control. Annu Rev Cell Dev Biol 30:615-646. doi:10.1146/annurev-cellbio-100913-013311

26. Buschbeck M, Hake SB (2017) Variants of core histones and their roles in cell fate decisions, development and cancer. Nature reviews Molecular cell biology 18:299-314.

doi:10.1038/nrm.2016.166

27. Wu G, Broniscer A, McEachron TA, Lu C, Paugh BS, Becksfort J, Qu C, Ding L, Huether R, Parker M, Zhang J, Gajjar A, Dyer MA, Mullighan CG, Gilbertson RJ, Mardis ER, Wilson RK, Downing JR, Ellison DW, Baker SJ (2012) Somatic histone H3 alterations in pediatric diffuse intrinsic pontine gliomas and non-brainstem glioblastomas. Nature genetics 44:251-253.

doi:ng.1102 [pii]

10.1038/ng.1102

28. Schwartzentruber J, Korshunov A, Liu XY, Jones DT, Pfaff E, Jacob K, Sturm D, Fontebasso AM, Quang DA, Tonjes M, Hovestadt V, Albrecht S, Kool M, Nantel A, Konermann C, Lindroth A, Jager N, Rausch T, Ryzhova M, Korbel JO, Hielscher T, Hauser P, Garami M, Klekner A, Bognar L, Ebinger M, Schuhmann MU, Scheurlen W, Pekrun A, Fruhwald MC, Roggendorf W, Kramm C, Durken M, Atkinson J, Lepage P, Montpetit A, Zakrzewska M, Zakrzewski K, Liberski PP, Dong Z, Siegel P, Kulozik AE, Zapatka M, Guha A, Malkin D, Felsberg J, Reifenberger G, von Deimling A, Ichimura K, Collins VP, Witt $H$, Milde T, Witt O, Zhang C, Castelo-Branco P, Lichter P, Faury D, Tabori U, Plass C, Majewski J, Pfister SM, Jabado N (2012) Driver mutations in histone H3.3 and chromatin remodelling genes in paediatric glioblastoma. Nature 482:226231. doi:nature10833 [pii]

10.1038 /nature10833

29. Fontebasso AM, Gayden T, Nikbakht H, Neirinck M, Papillon-Cavanagh S, Majewski J, Jabado N (2014) Epigenetic dysregulation: a novel pathway of oncogenesis in pediatric brain tumors. Acta neuropathologica 128:615-627. doi:10.1007/s00401-014-1325-8

30. Sturm D, Bender S, Jones DT, Lichter P, Grill J, Becher O, Hawkins C, Majewski J, Jones C, Costello JF, lavarone A, Aldape K, Brennan CW, Jabado N, Pfister SM (2014) Paediatric and adult glioblastoma: multiform (epi)genomic culprits emerge. Nature reviews Cancer 14:92-107. doi:10.1038/nrc3655

31. Nikbakht H, Panditharatna E, Mikael LG, Li R, Gayden T, Osmond M, Ho CY, Kambhampati M, Hwang El, Faury D, Siu A, Papillon-Cavanagh S, Bechet D, Ligon KL, Ellezam B, Ingram WJ, Stinson C, Moore AS, Warren KE, Karamchandani J, Packer RJ, Jabado N, Majewski J, Nazarian J (2016) Spatial and temporal homogeneity of driver mutations in diffuse intrinsic pontine glioma. Nature communications 7:11185. doi:10.1038/ncomms11185

32. Harutyunyan AS, Krug B, Chen H, Papillon-Cavanagh S, Zeinieh M, De Jay N, Deshmukh S, Chen CCL, Belle J, Mikael LG, Marchione DM, Li R, Nikbakht H, Hu B, Cagnone G, Cheung WA, Mohammadnia A, Bechet D, Faury D, McConechy MK, Pathania M, Jain SU, Ellezam B, Weil AG, Montpetit A, Salomoni P, Pastinen T, Lu C, Lewis PW, Garcia BA, Kleinman CL, Jabado N, Majewski J (2019) H3K27M induces defective chromatin spread of PRC2-mediated repressive 
$\mathrm{H} 3 \mathrm{~K} 27 \mathrm{me} 2 / \mathrm{me} 3$ and is essential for glioma tumorigenesis. Nature communications 10:1262. doi:10.1038/s41467-019-09140-x

33. Nacev BA, Feng L, Bagert JD, Lemiesz AE, Gao J, Soshnev AA, Kundra R, Schultz N, Muir TW, Allis CD (2019) The expanding landscape of 'oncohistone' mutations in human cancers. Nature 567:473-478. doi:10.1038/s41586-019-1038-1

34. Witt O, Albig W, Doenecke D (1996) Testis-specific expression of a novel human H3 histone gene. Exp Cell Res 229:301-306. doi:S0014-4827(96)90375-4 [pii]

10.1006/excr.1996.0375

35. Urahama T, Harada A, Maehara K, Horikoshi N, Sato K, Sato Y, Shiraishi K, Sugino N,

Osakabe A, Tachiwana H, Kagawa W, Kimura H, Ohkawa Y, Kurumizaka H (2016) Histone H3.5 forms an unstable nucleosome and accumulates around transcription start sites in human testis.

Epigenetics \& chromatin 9:2. doi:10.1186/s13072-016-0051-y

36. Wiedemann SM, Mildner SN, Bonisch C, Israel L, Maiser A, Matheisl S, Straub T, Merkl R, Leonhardt H, Kremmer E, Schermelleh L, Hake SB (2010) Identification and characterization of two novel primate-specific histone $\mathrm{H} 3$ variants, H3.X and H3.Y. The Journal of cell biology 190:777-791. doi:jcb.201002043 [pii]

10.1083/jcb.201002043

37. Hake SB, Garcia BA, Duncan EM, Kauer M, Dellaire G, Shabanowitz J, Bazett-Jones DP, Allis CD, Hunt DF (2006) Expression patterns and post-translational modifications associated with mammalian histone $\mathrm{H} 3$ variants. The Journal of biological chemistry 281:559-568.

doi:10.1074/jbc.M509266200

38. Ahmad K, Henikoff S (2002) The histone variant H3.3 marks active chromatin by replicationindependent nucleosome assembly. Molecular cell 9:1191-1200. doi:S1097276502005427 [pii] 39. Ray-Gallet D, Woolfe A, Vassias I, Pellentz C, Lacoste N, Puri A, Schultz DC, Pchelintsev NA, Adams PD, Jansen LE, Almouzni G (2011) Dynamics of histone H3 deposition in vivo reveal a nucleosome gap-filling mechanism for $\mathrm{H} 3.3$ to maintain chromatin integrity. Molecular cell 44:928-941. doi:10.1016/j.molcel.2011.12.006

40. Latreille D, Bluy L, Benkirane M, Kiernan RE (2014) Identification of histone 3 variant 2 interacting factors. Nucleic acids research 42:3542-3550. doi:10.1093/nar/gkt1355

41. Polo SE, Roche D, Almouzni G (2006) New histone incorporation marks sites of UV repair in human cells. Cell 127:481-493. doi:S0092-8674(06)01277-3 [pii]

10.1016/j.cell.2006.08.049

42. Polo SE, Almouzni G (2015) Chromatin dynamics after DNA damage: The legacy of the access-repair-restore model. DNA repair 36:114-121. doi:10.1016/j.dnarep.2015.09.014 43. Hake SB, Garcia BA, Kauer M, Baker SP, Shabanowitz J, Hunt DF, Allis CD (2005) Serine 31 phosphorylation of histone variant $\mathrm{H} 3.3$ is specific to regions bordering centromeres in metaphase chromosomes. Proceedings of the National Academy of Sciences of the United States of America 102:6344-6349. doi:0502413102 [pii]

10.1073/pnas.0502413102

44. Thorne JL, Ouboussad L, Lefevre PF (2012) Heterochromatin protein 1 gamma and IkappaB kinase alpha interdependence during tumour necrosis factor gene transcription elongation in activated macrophages. Nucleic acids research 40:7676-7689. doi:10.1093/nar/gks509 45. Truong DM, Boeke JD (2017) Resetting the Yeast Epigenome with Human Nucleosomes. Cell 171:1508-1519 e1513. doi:10.1016/j.cell.2017.10.043

46. Bramlage B, Kosciessa U, Doenecke D (1997) Differential expression of the murine histone genes H3.3A and H3.3B. Differentiation 62:13-20

47. Jang CW, Shibata Y, Starmer J, Yee D, Magnuson T (2015) Histone H3.3 maintains genome integrity during mammalian development. Genes \& development 29:1377-1392.

doi:10.1101/gad.264150.115 
48. Maehara K, Harada A, Sato Y, Matsumoto M, Nakayama KI, Kimura H, Ohkawa Y (2015)

Tissue-specific expression of histone $\mathrm{H} 3$ variants diversified after species separation.

Epigenetics \& chromatin 8:35. doi:10.1186/s13072-015-0027-3

49. Wu RS, Tsai S, Bonner WM (1982) Patterns of histone variant synthesis can distinguish G0

from G1 cells. Cell 31:367-374. doi:0092-8674(82)90130-1 [pii]

50. Rogakou EP, Sekeri-Pataryas KE (1999) Histone variants of H2A and H3 families are

regulated during in vitro aging in the same manner as during differentiation. Experimental

gerontology 34:741-754

51. Pina B, Suau $P$ (1987) Changes in the proportions of histone $H 1$ subtypes in brain cortical

neurons. FEBS letters 210:161-164

52. Loppin B, Bonnefoy E, Anselme C, Laurencon A, Karr TL, Couble P (2005) The histone H3.3 chaperone HIRA is essential for chromatin assembly in the male pronucleus. Nature 437:1386-

1390. doi:nature04059 [pii]

10.1038/nature04059

53. Torres-Padilla ME, Bannister AJ, Hurd PJ, Kouzarides T, Zernicka-Goetz M (2006) Dynamic distribution of the replacement histone variant $\mathrm{H} 3.3$ in the mouse oocyte and preimplantation embryos. Int J Dev Biol 50:455-461. doi:052073mt [pii]

$10.1387 / \mathrm{ijdb} .052073 \mathrm{mt}$

54. van der Heijden GW, Dieker JW, Derijck AA, Muller S, Berden JH, Braat DD, van der Vlag J, de Boer $\mathrm{P}$ (2005) Asymmetry in histone H3 variants and lysine methylation between paternal and maternal chromatin of the early mouse zygote. Mechanisms of development 122:1008-1022. doi:10.1016/j.mod.2005.04.009

55. Goldberg AD, Banaszynski LA, Noh KM, Lewis PW, Elsaesser SJ, Stadler S, Dewell S, Law M, Guo X, Li X, Wen D, Chapgier A, DeKelver RC, Miller JC, Lee YL, Boydston EA, Holmes MC, Gregory PD, Greally JM, Rafii S, Yang C, Scambler PJ, Garrick D, Gibbons RJ, Higgs DR, Cristea IM, Urnov FD, Zheng D, Allis CD (2010) Distinct factors control histone variant H3.3 localization at specific genomic regions. Cell 140:678-691. doi:S0092-8674(10)00004-8 [pii] 10.1016/j.cell.2010.01.003

56. Drané P, Ouararhni K, Depaux A, Shuaib M, Hamiche A (2010) The death-associated protein DAXX is a novel histone chaperone involved in the replication-independent deposition of H3.3. Genes \& development 24:1253-1265. doi:gad.566910 [pii]

10.1101/gad.566910

57. Tachiwana H, Osakabe A, Shiga T, Miya Y, Kimura H, Kagawa W, Kurumizaka H (2011) Structures of human nucleosomes containing major histone H3 variants. Acta crystallographica Section D, Biological crystallography 67:578-583. doi:10.1107/S0907444911014818

58. Jin C, Felsenfeld G (2007) Nucleosome stability mediated by histone variants $\mathrm{H} 3.3$ and H2A.Z. Genes \& development 21:1519-1529. doi:21/12/1519 [pii]

10.1101/gad.1547707

59. Chen P, Zhao J, Wang Y, Wang M, Long $H$, Liang $D$, Huang L, Wen Z, Li W, Li X, Feng $H$, Zhao H, Zhu P, Li M, Wang QF, Li G (2013) H3.3 actively marks enhancers and primes gene transcription via opening higher-ordered chromatin. Genes \& development 27:2109-2124. doi:10.1101/gad.222174.113

60. Szenker E, Lacoste N, Almouzni G (2012) A developmental requirement for HIRAdependent H3.3 deposition revealed at gastrulation in Xenopus. Cell reports 1:730-740. doi:10.1016/j.celrep.2012.05.006

61. Earnshaw WC, Rothfield N (1985) Identification of a family of human centromere proteins using autoimmune sera from patients with scleroderma. Chromosoma 91:313-321

62. Palmer DK, O'Day K, Trong HL, Charbonneau H, Margolis RL (1991) Purification of the centromere-specific protein CENP-A and demonstration that it is a distinctive histone.

Proceedings of the National Academy of Sciences of the United States of America 88:37343738 
63. Wolffe AP (1995) Centromeric chromatin. Histone deviants. Current biology : CB 5:452-454

64. Drinnenberg IA, Henikoff S, Malik HS (2016) Evolutionary Turnover of Kinetochore Proteins:

A Ship of Theseus? Trends in cell biology 26:498-510. doi:10.1016/j.tcb.2016.01.005

65. Tachiwana H, Kagawa W, Shiga T, Osakabe A, Miya Y, Saito K, Hayashi-Takanaka Y, Oda

T, Sato M, Park SY, Kimura H, Kurumizaka H (2011) Crystal structure of the human centromeric nucleosome containing CENP-A. Nature 476:232-235. doi:10.1038/nature10258

66. Lacoste N, Woolfe A, Tachiwana H, Garea AV, Barth T, Cantaloube S, Kurumizaka H, Imhof A, Almouzni G (2014) Mislocalization of the centromeric histone variant CenH3/CENP-A in human cells depends on the chaperone DAXX. Molecular cell 53:631-644.

doi:10.1016/j.molcel.2014.01.018

67. Geiss CP, Keramisanou D, Sekulic N, Scheffer MP, Black BE, Frangakis AS (2014) CENP-A arrays are more condensed than canonical arrays at low ionic strength. Biophysical journal 106:875-882. doi:10.1016/j.bpj.2014.01.005

68. Jansen LE, Black BE, Foltz DR, Cleveland DW (2007) Propagation of centromeric chromatin requires exit from mitosis. The Journal of cell biology 176:795-805. doi:jcb.200701066 [pii] 10.1083/jcb.200701066

69. Muller S, Almouzni G (2017) Chromatin dynamics during the cell cycle at centromeres. Nature reviews Genetics 18:192-208. doi:10.1038/nrg.2016.157

70. Hoffmann S, Dumont M, Barra V, Ly P, Nechemia-Arbely Y, McMahon MA, Herve S, Cleveland DW, Fachinetti D (2016) CENP-A Is Dispensable for Mitotic Centromere Function after Initial Centromere/Kinetochore Assembly. Cell reports 17:2394-2404.

doi:10.1016/j.celrep.2016.10.084

71. Howman EV, Fowler KJ, Newson AJ, Redward S, MacDonald AC, Kalitsis P, Choo KH (2000) Early disruption of centromeric chromatin organization in centromere protein A (Cenpa) null mice. Proceedings of the National Academy of Sciences of the United States of America 97:1148-1153

72. Gurard-Levin ZA, Almouzni G (2014) Histone modifications and a choice of variant: a language that helps the genome express itself. F1000Prime Rep 6:76. doi:10.12703/P6-76 73. Laskey RA, Mills AD, Morris NR (1977) Assembly of SV40 chromatin in a cell-free system from Xenopus eggs. Cell 10:237-243. doi:0092-8674(77)90217-3 [pii]

74. De Koning L, Corpet A, Haber JE, Almouzni G (2007) Histone chaperones: an escort network regulating histone traffic. Nature structural \& molecular biology 14:997-1007.

doi:nsmb1318 [pii]

10.1038/nsmb1318

75. Dilworth SM, Black SJ, Laskey RA (1987) Two complexes that contain histones are required for nucleosome assembly in vitro: role of nucleoplasmin and N1 in Xenopus egg extracts. Cell 51:1009-1018

76. Hammond CM, Stromme CB, Huang H, Patel DJ, Groth A (2017) Histone chaperone networks shaping chromatin function. Nature reviews Molecular cell biology 18:141-158. doi:10.1038/nrm.2016.159

77. Grover P, Asa JS, Campos El (2018) H3-H4 Histone Chaperone Pathways. Annual review of genetics 52:109-130. doi:10.1146/annurev-genet-120417-031547

78. Smith S, Stillman B (1989) Purification and characterization of CAF-I, a human cell factor required for chromatin assembly during DNA replication in vitro. Cell 58:15-25. doi:00928674(89)90398-X [pii]

79. Moggs JG, Grandi P, Quivy JP, Jonsson ZO, Hubscher U, Becker PB, Almouzni G (2000) A CAF-1-PCNA-mediated chromatin assembly pathway triggered by sensing DNA damage.

Molecular and cellular biology 20:1206-1218

80. Shibahara K, Stillman B (1999) Replication-dependent marking of DNA by PCNA facilitates CAF-1-coupled inheritance of chromatin. Cell 96:575-585 
81. Gerard A, Koundrioukoff S, Ramillon V, Sergere JC, Mailand N, Quivy JP, Almouzni G (2006) The replication kinase Cdc7-Dbf4 promotes the interaction of the p150 subunit of chromatin assembly factor 1 with proliferating cell nuclear antigen. EMBO reports 7:817-823. doi:10.1038/sj.embor.7400750

82. Quivy JP, Grandi P, Almouzni G (2001) Dimerization of the largest subunit of chromatin assembly factor 1: importance in vitro and during Xenopus early development. The EMBO journal 20:2015-2027. doi:10.1093/emboj/20.8.2015

83. Quivy JP, Roche D, Kirschner D, Tagami H, Nakatani Y, Almouzni G (2004) A CAF-1 dependent pool of HP1 during heterochromatin duplication. The EMBO journal 23:3516-3526. doi:10.1038/sj.emboj.7600362

7600362 [pii]

84. Quivy JP, Gerard A, Cook AJ, Roche D, Almouzni G (2008) The HP1-p150/CAF-1 interaction is required for pericentric heterochromatin replication and S-phase progression in mouse cells. Nature structural \& molecular biology 15:972-979

85. Hassig CA, Fleischer TC, Billin AN, Schreiber SL, Ayer DE (1997) Histone deacetylase activity is required for full transcriptional repression by $\mathrm{mSin} 3 \mathrm{~A}$. Cell 89:341-347

86. Tagami H, Ray-Gallet D, Almouzni G, Nakatani Y (2004) Histone H3.1 and H3.3 complexes mediate nucleosome assembly pathways dependent or independent of DNA synthesis. Cell 116:51-61. doi:S009286740301064X [pii]

87. Sauer PV, Gu Y, Liu WH, Mattiroli F, Panne D, Luger K, Churchill ME (2018) Mechanistic insights into histone deposition and nucleosome assembly by the chromatin assembly factor-1. Nucleic acids research 46:9907-9917. doi:10.1093/nar/gky823

88. Houlard M, Berlivet S, Probst AV, Quivy JP, Hery P, Almouzni G, Gerard M (2006) CAF-1 is essential for heterochromatin organization in pluripotent embryonic cells. PLoS genetics 2:e181. doi:10.1371/journal.pgen.0020181

89. Ishiuchi T, Enriquez-Gasca R, Mizutani E, Boskovic A, Ziegler-Birling C, Rodriguez-Terrones D, Wakayama T, Vaquerizas JM, Torres-Padilla ME (2015) Early embryonic-like cells are induced by downregulating replication-dependent chromatin assembly. Nature structural \& molecular biology 22:662-671. doi:10.1038/nsmb.3066

90. Cheloufi S, Elling U, Hopfgartner B, Jung YL, Murn J, Ninova M, Hubmann M, Badeaux Al, Euong Ang C, Tenen D, Wesche DJ, Abazova N, Hogue M, Tasdemir N, Brumbaugh J, Rathert P, Jude J, Ferrari F, Blanco A, Fellner M, Wenzel D, Zinner M, Vidal SE, Bell O, Stadtfeld M, Chang HY, Almouzni G, Lowe SW, Rinn J, Wernig M, Aravin A, Shi Y, Park PJ, Penninger JM, Zuber J, Hochedlinger K (2015) The histone chaperone CAF-1 safeguards somatic cell identity. Nature 528:218-224. doi:10.1038/nature15749

91. Ng C, Aichinger M, Nguyen T, Au C, Najar T, Wu L, Mesa KR, Liao W, Quivy JP, Hubert B, Almouzni G, Zuber J, Littman DR (2019) The histone chaperone CAF-1 cooperates with the DNA methyltransferases to maintain Cd4 silencing in cytotoxic T cells. Genes \& development. doi:10.1101/gad.322024.118

92. Ricketts MD, Marmorstein R (2017) A Molecular Prospective for HIRA Complex Assembly and H3.3-Specific Histone Chaperone Function. J Mol Biol 429:1924-1933.

doi:10.1016/j.jmb.2016.11.010

93. Dyer MA, Qadeer ZA, Valle-Garcia D, Bernstein E (2017) ATRX and DAXX: Mechanisms and Mutations. Cold Spring Harbor perspectives in medicine 7.

doi:10.1101/cshperspect.a026567

94. Lamour V, Lecluse Y, Desmaze C, Spector M, Bodescot M, Aurias A, Osley MA, Lipinski M (1995) A human homolog of the S. cerevisiae HIR1 and HIR2 transcriptional repressors cloned from the DiGeorge syndrome critical region. Human molecular genetics 4:791-799

95. Ray-Gallet D, Quivy JP, Scamps C, Martini EM, Lipinski M, Almouzni G (2002) HIRA is critical for a nucleosome assembly pathway independent of DNA synthesis. Molecular cell 9:1091-1100. doi:S1097276502005269 [pii] 
96. Banumathy G, Somaiah N, Zhang R, Tang Y, Hoffmann J, Andrake M, Ceulemans H, Schultz D, Marmorstein R, Adams PD (2009) Human UBN1 is an ortholog of yeast Hpc2p and has an essential role in the HIRA/ASF1a chromatin-remodeling pathway in senescent cells. Molecular and cellular biology 29:758-770. doi:MCB.01047-08 [pii] 10.1128/MCB.01047-08

97. Rai TS, Puri A, McBryan T, Hoffman J, Tang Y, Pchelintsev NA, van Tuyn J, Marmorstein R, Schultz DC, Adams PD (2011) Human CABIN1 is a functional member of the human HIRA/UBN1/ASF1a histone H3.3 chaperone complex. Molecular and cellular biology 31:41074118. doi:MCB.05546-11 [pii]

10.1128/MCB.05546-11

98. Aho S, Buisson M, Pajunen T, Ryoo YW, Giot JF, Gruffat H, Sergeant A, Uitto J (2000) Ubinuclein, a novel nuclear protein interacting with cellular and viral transcription factors. The Journal of cell biology 148:1165-1176

99. Balaji S, Iyer LM, Aravind L (2009) HPC2 and ubinuclein define a novel family of histone chaperones conserved throughout eukaryotes. Mol Biosyst 5:269-275. doi:10.1039/b816424j 100. Ricketts MD, Frederick B, Hoff H, Tang Y, Schultz DC, Singh Rai T, Grazia Vizioli M, Adams PD, Marmorstein R (2015) Ubinuclein-1 confers histone H3.3-specific-binding by the HIRA histone chaperone complex. Nature communications 6:7711. doi:10.1038/ncomms8711 101. Sun L, Youn HD, Loh C, Stolow M, He W, Liu JO (1998) Cabin 1, a negative regulator for calcineurin signaling in T lymphocytes. Immunity 8:703-711. doi:S1074-7613(00)80575-0 [pii] 102. Amin AD, Vishnoi N, Prochasson P (2013) A global requirement for the HIR complex in the assembly of chromatin. Biochim Biophys Acta 1819:264-276

103. Ray-Gallet D, Ricketts MD, Sato Y, Gupta K, Boyarchuk E, Senda T, Marmorstein R, Almouzni G (2018) Functional activity of the H3.3 histone chaperone complex HIRA requires trimerization of the HIRA subunit. Nature communications 9:3103. doi:10.1038/s41467-01805581-y

104. Xiong C, Wen Z, Yu J, Chen J, Liu CP, Zhang X, Chen P, Xu RM, Li G (2018) UBN1/2 of $\mathrm{HIRA}$ complex is responsible for recognition and deposition of $\mathrm{H} 3.3$ at cis-regulatory elements of genes in mouse ES cells. BMC biology 16:110. doi:10.1186/s12915-018-0573-9

105. Roberts C, Sutherland HF, Farmer H, Kimber W, Halford S, Carey A, Brickman JM, Wynshaw-Boris A, Scambler PJ (2002) Targeted mutagenesis of the Hira gene results in gastrulation defects and patterning abnormalities of mesoendodermal derivatives prior to early embryonic lethality. Molecular and cellular biology 22:2318-2328

106. Yang X, Khosravi-Far R, Chang HY, Baltimore D (1997) Daxx, a novel Fas-binding protein that activates JNK and apoptosis. Cell 89:1067-1076

107. Weatherall DJ, Higgs DR, Bunch C, Old JM, Hunt DM, Pressley L, Clegg JB, Bethlenfalvay NC, Sjolin S, Koler RD, Magenis E, Francis JL, Bebbington D (1981) Hemoglobin H disease and mental retardation: a new syndrome or a remarkable coincidence? The New England journal of medicine 305:607-612. doi:10.1056/NEJM198109103051103

108. Gibbons RJ, Picketts DJ, Villard L, Higgs DR (1995) Mutations in a putative global transcriptional regulator cause $\mathrm{X}$-linked mental retardation with alpha-thalassemia (ATR-X syndrome). Cell 80:837-845

109. Picketts DJ, Higgs DR, Bachoo S, Blake DJ, Quarrell OW, Gibbons RJ (1996) ATRX encodes a novel member of the SNF2 family of proteins: mutations point to a common mechanism underlying the ATR-X syndrome. Human molecular genetics 5:1899-1907 110. Langst G, Manelyte L (2015) Chromatin Remodelers: From Function to Dysfunction. Genes 6:299-324. doi:10.3390/genes6020299

111. Elsaesser SJ, Allis CD (2010) HIRA and Daxx Constitute Two Independent Histone H3.3Containing Predeposition Complexes. Cold Spring Harbor symposia on quantitative biology.

doi:sqb.2010.75.008 [pii]

10.1101/sqb.2010.75.008 
112. Xue Y, Gibbons R, Yan Z, Yang D, McDowell TL, Sechi S, Qin J, Zhou S, Higgs D, Wang W (2003) The ATRX syndrome protein forms a chromatin-remodeling complex with Daxx and localizes in promyelocytic leukemia nuclear bodies. Proceedings of the National Academy of Sciences of the United States of America 100:10635-10640. doi:10.1073/pnas. 1937626100 1937626100 [pii]

113. Elsasser SJ, Huang H, Lewis PW, Chin JW, Allis CD, Patel DJ (2012) DAXX envelops a histone H3.3-H4 dimer for H3.3-specific recognition. Nature 491:560-565.

doi:10.1038/nature11608

114. Liu CP, Xiong C, Wang M, Yu Z, Yang N, Chen P, Zhang Z, Li G, Xu RM (2012) Structure of the variant histone H3.3-H4 heterodimer in complex with its chaperone DAXX. Nature structural \& molecular biology 19:1287-1292. doi:10.1038/nsmb.2439

115. Arimura Y, Shirayama K, Horikoshi N, Fujita R, Taguchi H, Kagawa W, Fukagawa T, Almouzni G, Kurumizaka H (2014) Crystal structure and stable property of the cancer-associated heterotypic nucleosome containing CENP-A and H3.3. Scientific reports 4:7115.

doi:10.1038/srep07115

116. Athwal RK, Walkiewicz MP, Baek S, Fu S, Bui M, Camps J, Ried T, Sung MH, Dalal Y (2015) CENP-A nucleosomes localize to transcription factor hotspots and subtelomeric sites in human cancer cells. Epigenetics \& chromatin 8:2. doi:10.1186/1756-8935-8-2

117. Shrestha RL, Ahn GS, Staples MI, Sathyan KM, Karpova TS, Foltz DR, Basrai MA (2017)

Mislocalization of centromeric histone $\mathrm{H} 3$ variant CENP-A contributes to chromosomal instability $(\mathrm{CIN})$ in human cells. Oncotarget 8:46781-46800. doi:10.18632/oncotarget.18108

118. Sharma AB, Dimitrov S, Hamiche A, Van Dyck E (2018) Centromeric and ectopic assembly of CENP-A chromatin in health and cancer: old marks and new tracks. Nucleic acids research. doi:10.1093/nar/gky1298

119. Hoelper D, Huang H, Jain AY, Patel DJ, Lewis PW (2017) Structural and mechanistic insights into ATRX-dependent and -independent functions of the histone chaperone DAXX. Nature communications 8:1193. doi:10.1038/s41467-017-01206-y 120. Michaelson JS, Bader D, Kuo F, Kozak C, Leder P (1999) Loss of Daxx, a promiscuously interacting protein, results in extensive apoptosis in early mouse development. Genes \& development 13:1918-1923

121. Garrick D, Sharpe JA, Arkell R, Dobbie L, Smith AJ, Wood WG, Higgs DR, Gibbons RJ (2006) Loss of Atrx affects trophoblast development and the pattern of X-inactivation in extraembryonic tissues. PLoS genetics 2:e58. doi:10.1371/journal.pgen.0020058

122. Voon HP, Hughes JR, Rode C, De La Rosa-Velazquez IA, Jenuwein T, Feil R, Higgs DR, Gibbons RJ (2015) ATRX Plays a Key Role in Maintaining Silencing at Interstitial Heterochromatic Loci and Imprinted Genes. Cell reports 11:405-418.

doi:10.1016/j.celrep.2015.03.036

123. Kato T, Sato N, Hayama S, Yamabuki T, Ito T, Miyamoto M, Kondo S, Nakamura Y, Daigo Y (2007) Activation of Holliday junction recognizing protein involved in the chromosomal stability and immortality of cancer cells. Cancer research 67:8544-8553. doi:0008-5472.CAN-07-1307 [pii]

10.1158/0008-5472.CAN-07-1307

124. Dunleavy EM, Roche D, Tagami H, Lacoste N, Ray-Gallet D, Nakamura Y, Daigo Y, Nakatani Y, Almouzni-Pettinotti G (2009) HJURP is a cell-cycle-dependent maintenance and deposition factor of CENP-A at centromeres. Cell 137:485-497. doi:S0092-8674(09)00254-2 [pii] 10.1016/j.cell.2009.02.040

125. Foltz DR, Jansen LE, Bailey AO, Yates JR, 3rd, Bassett EA, Wood S, Black BE, Cleveland DW (2009) Centromere-specific assembly of CENP-a nucleosomes is mediated by HJURP. Cell 137:472-484. doi:S0092-8674(09)00253-0 [pii]

10.1016/j.cell.2009.02.039 
126. Black BE, Jansen LE, Maddox PS, Foltz DR, Desai AB, Shah JV, Cleveland DW (2007) Centromere identity maintained by nucleosomes assembled with histone $\mathrm{H} 3$ containing the CENP-A targeting domain. Molecular cell 25:309-322. doi:10.1016/j.molcel.2006.12.018 127. Hu H, Liu Y, Wang M, Fang J, Huang H, Yang N, Li Y, Wang J, Yao X, Shi Y, Li G, Xu RM (2011) Structure of a CENP-A-histone H4 heterodimer in complex with chaperone HJURP. Genes \& development 25:901-906. doi:10.1101/gad.2045111

128. Zasadzinska E, Barnhart-Dailey MC, Kuich PH, Foltz DR (2013) Dimerization of the CENPA assembly factor HJURP is required for centromeric nucleosome deposition. The EMBO journal 32:2113-2124. doi:10.1038/emboj.2013.142

129. Tachiwana H, Muller S, Blumer J, Klare K, Musacchio A, Almouzni G (2015) HJURP involvement in de novo CenH3(CENP-A) and CENP-C recruitment. Cell reports 11:22-32. doi:10.1016/j.celrep.2015.03.013

130. Le S, Davis C, Konopka JB, Sternglanz R (1997) Two new S-phase-specific genes from Saccharomyces cerevisiae. Yeast 13:1029-1042. doi:10.1002/(SICI)1097-

0061(19970915)13:11<1029::AID-YEA160>3.0.CO;2-1

131. Natsume R, Eitoku M, Akai Y, Sano N, Horikoshi M, Senda T (2007) Structure and function of the histone chaperone CIA/ASF1 complexed with histones H3 and H4. Nature 446:338-341. doi:10.1038/nature05613

132. English CM, Adkins MW, Carson JJ, Churchill ME, Tyler JK (2006) Structural basis for the histone chaperone activity of Asf1. Cell 127:495-508. doi:10.1016/j.cell.2006.08.047

133. Tyler JK, Adams CR, Chen SR, Kobayashi R, Kamakaka RT, Kadonaga JT (1999) The

RCAF complex mediates chromatin assembly during DNA replication and repair. Nature 402:555-560. doi:10.1038/990147

134. Mello JA, Sillje HH, Roche DM, Kirschner DB, Nigg EA, Almouzni G (2002) Human Asf1 and $\mathrm{CAF}-1$ interact and synergize in a repair-coupled nucleosome assembly pathway. EMBO reports 3:329-334.

135. Abascal F, Corpet A, Gurard-Levin ZA, Juan D, Ochsenbein F, Rico D, Valencia A, Almouzni G (2013) Subfunctionalization via adaptive evolution influenced by genomic context: the case of histone chaperones ASF1a and ASF1b. Mol Biol Evol 30:1853-1866.

doi:10.1093/molbev/mst086

136. Daganzo SM, Erzberger JP, Lam WM, Skordalakes E, Zhang R, Franco AA, Brill SJ, Adams PD, Berger JM, Kaufman PD (2003) Structure and function of the conserved core of histone deposition protein Asf1. Current biology : CB 13:2148-2158. doi:S0960982203008698 [pii]

137. Tang Y, Poustovoitov MV, Zhao K, Garfinkel M, Canutescu A, Dunbrack R, Adams PD, Marmorstein R (2006) Structure of a human ASF1a-HIRA complex and insights into specificity of histone chaperone complex assembly. Nature structural \& molecular biology 13:921-929.

doi:nsmb1147 [pii]

10.1038/nsmb1147

138. Mousson F, Lautrette A, Thuret JY, Agez M, Courbeyrette R, Amigues B, Becker E, Neumann JM, Guerois R, Mann C, Ochsenbein F (2005) Structural basis for the interaction of Asf1 with histone $\mathrm{H} 3$ and its functional implications. Proceedings of the National Academy of Sciences of the United States of America 102:5975-5980. doi:10.1073/pnas.0500149102 139. Groth A, Corpet A, Cook AJ, Roche D, Bartek J, Lukas J, Almouzni G (2007) Regulation of replication fork progression through histone supply and demand. Science 318:1928-1931. doi:318/5858/1928 [pii]

10.1126/science.1148992

140. Clement C, Orsi GA, Gatto A, Boyarchuk E, Forest A, Hajj B, Mine-Hattab J, Garnier M, Gurard-Levin ZA, Quivy JP, Almouzni G (2018) High-resolution visualization of H3 variants during replication reveals their controlled recycling. Nature communications 9:3181.

doi:10.1038/s41467-018-05697-1 
141. Riera A, Barbon M, Noguchi Y, Reuter LM, Schneider S, Speck C (2017) From structure to mechanism-understanding initiation of DNA replication. Genes \& development 31:1073-1088. doi:10.1101/gad.298232.117

142. Ishimi Y, Komamura-Kohno Y, Arai K, Masai H (2001) Biochemical activities associated with mouse Mcm2 protein. The Journal of biological chemistry 276:42744-42752.

doi:10.1074/jbc.M106861200

143. Foltman M, Evrin C, De Piccoli G, Jones RC, Edmondson RD, Katou Y, Nakato R, Shirahige K, Labib K (2013) Eukaryotic replisome components cooperate to process histones during chromosome replication. Cell reports 3:892-904. doi:10.1016/j.celrep.2013.02.028 144. Huang H, Stromme CB, Saredi G, Hodl M, Strandsby A, Gonzalez-Aguilera C, Chen S, Groth A, Patel DJ (2015) A unique binding mode enables MCM2 to chaperone histones H3-H4 at replication forks. Nature structural \& molecular biology 22:618-626. doi:10.1038/nsmb.3055 145. Richet N, Liu D, Legrand P, Velours C, Corpet A, Gaubert A, Bakail M, Moal-Raisin G, Guerois R, Compper C, Besle A, Guichard B, Almouzni G, Ochsenbein F (2015) Structural insight into how the human helicase subunit MCM2 may act as a histone chaperone together with ASF1 at the replication fork. Nucleic acids research 43:1905-1917. doi:10.1093/nar/gkv021 146. Clement C, Almouzni G (2015) MCM2 binding to histones H3-H4 and ASF1 supports a tetramer-to-dimer model for histone inheritance at the replication fork. Nature structural \& molecular biology 22:587-589. doi:10.1038/nsmb.3067

147. Li Y, Pursell ZF, Linn S (2000) Identification and cloning of two histone fold motif-containing subunits of HeLa DNA polymerase epsilon. The Journal of biological chemistry 275:31554

148. Bellelli R, Belan O, Pye VE, Clement C, Maslen SL, Skehel JM, Cherepanov P, Almouzni G, Boulton SJ (2018) POLE3-POLE4 Is a Histone H3-H4 Chaperone that Maintains Chromatin Integrity during DNA Replication. Molecular cell 72:112-126 e115.

doi:10.1016/j.molcel.2018.08.043

149. Yu C, Gan H, Serra-Cardona A, Zhang L, Gan S, Sharma S, Johansson E, Chabes A, Xu RM, Zhang Z (2018) A mechanism for preventing asymmetric histone segregation onto replicating DNA strands. Science 361:1386-1389. doi:10.1126/science.aat8849

150. Torne J, Orsi GA, Ray-Gallet D, Almouzni G (2018) Imaging Newly Synthesized and Old Histone Variant Dynamics Dependent on Chaperones Using the SNAP-Tag System. Methods Mol Biol 1832:207-221. doi:10.1007/978-1-4939-8663-7_11

151. Gaillard PH, Martini EM, Kaufman PD, Stillman B, Moustacchi E, Almouzni G (1996) Chromatin assembly coupled to DNA repair: a new role for chromatin assembly factor I. Cell 86:887-896. doi:S0092-8674(00)80164-6 [pii]

152. Martini E, Roche DM, Marheineke K, Verreault A, Almouzni G (1998) Recruitment of phosphorylated chromatin assembly factor 1 to chromatin after UV irradiation of human cells. The Journal of cell biology 143:563-575

153. Keller C, Krude T (2000) Requirement of Cyclin/Cdk2 and protein phosphatase 1 activity for chromatin assembly factor 1 -dependent chromatin assembly during DNA synthesis. The Journal of biological chemistry 275:35512-35521. doi:10.1074/jbc.M003073200

154. Sarai N, Nimura K, Tamura T, Kanno T, Patel MC, Heightman TD, Ura K, Ozato K (2013) WHSC 1 links transcription elongation to HIRA-mediated histone H3.3 deposition. The EMBO journal 32:2392-2406. doi:10.1038/emboj.2013.176

155. Zhang $\mathrm{H}$, Gan $\mathrm{H}$, Wang Z, Lee JH, Zhou H, Ordog T, Wold MS, Ljungman M, Zhang Z (2017) RPA Interacts with HIRA and Regulates H3.3 Deposition at Gene Regulatory Elements in Mammalian Cells. Molecular cell 65:272-284. doi:10.1016/j.molcel.2016.11.030

156. Soni S, Pchelintsev N, Adams PD, Bieker JJ (2014) Transcription factor EKLF (KLF1) recruitment of the histone chaperone HIRA is essential for beta-globin gene expression.

Proceedings of the National Academy of Sciences of the United States of America 111:1333713342. doi:10.1073/pnas.1405422111 
157. Lee JS, Zhang Z (2016) O-linked N-acetylglucosamine transferase (OGT) interacts with the histone chaperone HIRA complex and regulates nucleosome assembly and cellular senescence. Proceedings of the National Academy of Sciences of the United States of America 113:E32133220. doi:10.1073/pnas. 1600509113

158. Yang JH, Song TY, Jo C, Park J, Lee HY, Song I, Hong S, Jung KY, Kim J, Han JW, Youn HD, Cho EJ (2016) Differential regulation of the histone chaperone HIRA during muscle cell differentiation by a phosphorylation switch. Exp Mol Med 48:e252. doi:10.1038/emm.2016.68 159. Adam S, Polo SE, Almouzni G (2013) Transcription Recovery after DNA Damage Requires Chromatin Priming by the H3.3 Histone Chaperone HIRA. Cell 155:94-106.

doi:10.1016/j.cell.2013.08.029

160. Cohen C, Corpet A, Roubille S, Maroui MA, Poccardi N, Rousseau A, Kleijwegt C, Binda O, Texier P, Sawtell N, Labetoulle M, Lomonte P (2018) Promyelocytic leukemia (PML) nuclear bodies (NBs) induce latent/quiescent HSV-1 genomes chromatinization through a PML

NB/Histone H3.3/H3.3 Chaperone Axis. PLoS pathogens 14:e1007313.

doi:10.1371/journal.ppat.1007313

161. Rai TS, Glass M, Cole JJ, Rather MI, Marsden M, Neilson M, Brock C, Humphreys IR, Everett RD, Adams PD (2017) Histone chaperone HIRA deposits histone H3.3 onto foreign viral DNA and contributes to anti-viral intrinsic immunity. Nucleic acids research 45:11673-11683. doi:10.1093/nar/gkx771

162. Placek BJ, Huang J, Kent JR, Dorsey J, Rice L, Fraser NW, Berger SL (2009) The histone variant $\mathrm{H} 3.3$ regulates gene expression during lytic infection with herpes simplex virus type 1. Journal of virology 83:1416-1421. doi:10.1128/JVI.01276-08

163. Schneiderman JI, Orsi GA, Hughes KT, Loppin B, Ahmad K (2012) Nucleosome-depleted chromatin gaps recruit assembly factors for the H3.3 histone variant. Proceedings of the National Academy of Sciences of the United States of America 109:19721-19726.

doi:10.1073/pnas.1206629109

164. Boyarchuk E, Filipescu D, Vassias I, Cantaloube S, Almouzni G (2014) The histone variant composition of centromeres is controlled by the pericentric heterochromatin state during the cell cycle. Journal of cell science 127:3347-3359. doi:10.1242/jcs.148189

165. Law MJ, Lower KM, Voon HP, Hughes JR, Garrick D, Viprakasit V, Mitson M, De Gobbi M, Marra M, Morris A, Abbott A, Wilder SP, Taylor S, Santos GM, Cross J, Ayyub H, Jones S, Ragoussis J, Rhodes D, Dunham I, Higgs DR, Gibbons RJ (2010) ATR-X syndrome protein targets tandem repeats and influences allele-specific expression in a size-dependent manner.

Cell 143:367-378. doi:10.1016/j.cell.2010.09.023

166. Elsasser SJ, Noh KM, Diaz N, Allis CD, Banaszynski LA (2015) Histone H3.3 is required for endogenous retroviral element silencing in embryonic stem cells. Nature 522:240-244.

doi:10.1038/nature14345

167. Clynes D, Jelinska C, Xella B, Ayyub H, Scott C, Mitson M, Taylor S, Higgs DR, Gibbons RJ (2015) Suppression of the alternative lengthening of telomere pathway by the chromatin remodelling factor ATRX. Nature communications 6:7538. doi:10.1038/ncomms8538 168. Sadic D, Schmidt K, Groh S, Kondofersky I, Ellwart J, Fuchs C, Theis FJ, Schotta G (2015) Atrx promotes heterochromatin formation at retrotransposons. EMBO reports 16:836-850. doi:10.15252/embr.201439937

169. Michod D, Bartesaghi S, Khelifi A, Bellodi C, Berliocchi L, Nicotera P, Salomoni P (2012) Calcium-dependent dephosphorylation of the histone chaperone DAXX regulates $\mathrm{H} 3.3$ loading and transcription upon neuronal activation. Neuron 74:122-135.

doi:10.1016/j.neuron.2012.02.021

170. Muller S, Montes de Oca R, Lacoste N, Dingli F, Loew D, Almouzni G (2014)

Phosphorylation and DNA binding of HJURP determine its centromeric recruitment and function in CenH3(CENP-A) loading. Cell reports 8:190-203. doi:10.1016/j.celrep.2014.06.002 
171. Wang J, Liu X, Dou Z, Chen L, Jiang H, Fu C, Fu G, Liu D, Zhang J, Zhu T, Fang J, Zang J, Cheng J, Teng M, Ding X, Yao X (2014) Mitotic regulator Mis18beta interacts with and specifies the centromeric assembly of molecular chaperone holliday junction recognition protein (HJURP). The Journal of biological chemistry 289:8326-8336. doi:10.1074/jbc.M113.529958

172. Yu Z, Zhou X, Wang W, Deng W, Fang J, Hu H, Wang Z, Li S, Cui L, Shen J, Zhai L, Peng S, Wong J, Dong S, Yuan Z, Ou G, Zhang X, Xu P, Lou J, Yang N, Chen P, Xu RM, Li G (2015) Dynamic phosphorylation of CENP-A at Ser68 orchestrates its cell-cycle-dependent deposition at centromeres. Developmental cell 32:68-81. doi:10.1016/j.devcel.2014.11.030 173. Niikura Y, Kitagawa R, Ogi H, Abdulle R, Pagala V, Kitagawa K (2015) CENP-A K124 Ubiquitylation Is Required for CENP-A Deposition at the Centromere. Developmental cell 32:589-603. doi:10.1016/j.devcel.2015.01.024

174. Zasadzinska E, Huang J, Bailey AO, Guo LY, Lee NS, Srivastava S, Wong KA, French BT, Black BE, Foltz DR (2018) Inheritance of CENP-A Nucleosomes during DNA Replication Requires HJURP. Developmental cell 47:348-362 e347. doi:10.1016/j.devcel.2018.09.003 175. Dunleavy EM, Almouzni G, Karpen GH (2011) H3.3 is deposited at centromeres in S phase as a placeholder for newly assembled CENP-A in G1 phase. Nucleus 2:1-12

176. Annunziato AT, Schindler RK, Riggs MG, Seale RL (1982) Association of newly synthesized histones with replicating and nonreplicating regions of chromatin. The Journal of biological chemistry 257:8507-8515

177. Jackson V, Chalkley $R$ (1981) A reevaluation of new histone deposition on replicating chromatin. The Journal of biological chemistry 256:5095-5103

178. Reveron-Gomez N, Gonzalez-Aguilera C, Stewart-Morgan KR, Petryk N, Flury V, Graziano S, Johansen JV, Jakobsen JS, Alabert C, Groth A (2018) Accurate Recycling of Parental Histones Reproduces the Histone Modification Landscape during DNA Replication. Molecular cell 72:239-249 e235. doi:10.1016/j.molcel.2018.08.010

179. Xu M, Long C, Chen X, Huang C, Chen S, Zhu B (2010) Partitioning of histone H3-H4 tetramers during DNA replication-dependent chromatin assembly. Science 328:94-98.

doi:328/5974/94 [pii]

10.1126/science. 1178994

180. Ray-Gallet D, Almouzni G (2010) Molecular biology. Mixing or not mixing. Science 328:5657. doi:328/5974/56 [pii]

10.1126/science. 1188653

181. Gan H, Serra-Cardona A, Hua X, Zhou H, Labib K, Yu C, Zhang Z (2018) The Mcm2-Ctf4Polalpha Axis Facilitates Parental Histone H3-H4 Transfer to Lagging Strands. Molecular cell 72:140-151 e143. doi:10.1016/j.molcel.2018.09.001

182. Petryk N, Dalby M, Wenger A, Stromme CB, Strandsby A, Andersson R, Groth A (2018) MCM2 promotes symmetric inheritance of modified histones during DNA replication. Science 361:1389-1392. doi:10.1126/science.aau0294

183. Simon AC, Zhou JC, Perera RL, van Deursen F, Evrin C, Ivanova ME, Kilkenny ML, Renault L, Kjaer S, Matak-Vinkovic D, Labib K, Costa A, Pellegrini L (2014) A Ctf4 trimer couples the CMG helicase to DNA polymerase alpha in the eukaryotic replisome. Nature 510:293-297. doi:10.1038/nature13234

184. Ahmad K, Henikoff S (2018) No strand left behind. Science 361:1311-1312. doi:10.1126/science.aav0871

185. Tran V, Lim C, Xie J, Chen X (2012) Asymmetric division of Drosophila male germline stem cell shows asymmetric histone distribution. Science 338:679-682. doi:10.1126/science.1226028 186. Garcia Del Arco A, Edgar BA, Erhardt S (2018) In Vivo Analysis of Centromeric Proteins Reveals a Stem Cell-Specific Asymmetry and an Essential Role in Differentiated, Nonproliferating Cells. Cell reports 22:1982-1993. doi:10.1016/j.celrep.2018.01.079 187. Adam S, Dabin J, Chevallier O, Leroy O, Baldeyron C, Corpet A, Lomonte P, Renaud O, Almouzni G, Polo SE (2016) Real-Time Tracking of Parental Histones Reveals Their 
Contribution to Chromatin Integrity Following DNA Damage. Molecular cell 64:65-78.

doi:10.1016/j.molcel.2016.08.019

188. Svensson JP, Shukla M, Menendez-Benito V, Norman-Axelsson U, Audergon P, Sinha I, Tanny JC, Allshire RC, Ekwall K (2015) A nucleosome turnover map reveals that the stability of histone H4 Lys20 methylation depends on histone recycling in transcribed chromatin. Genome research 25:872-883. doi:10.1101/gr.188870.114 
Genomic organization, mRNA structure and temporal expression of H3.1/H3.2, H3.3 and CenH3 ${ }^{\text {CENP-A }}$

\section{Replicative H3}

H3.1

H3.2

Several genes in clusters

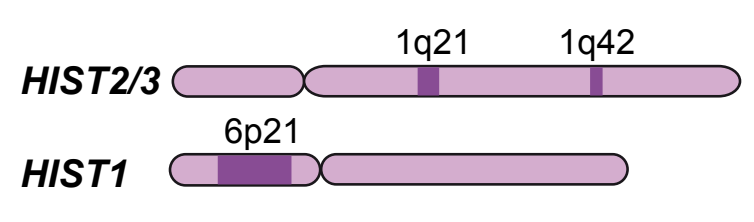

H3.1/H3.2

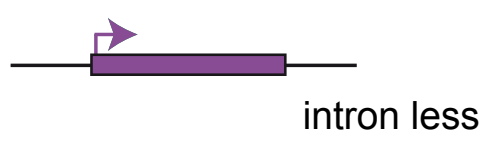

mRNA H3.1/H3.2

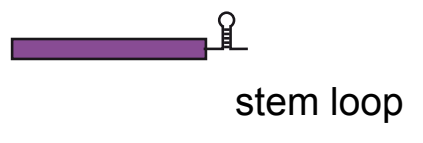

Peak in S phase

\section{H3 Variants}

H3.3

Two single genes

One single gene

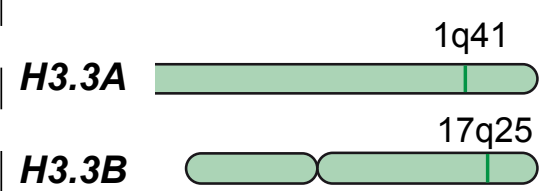

CenH3

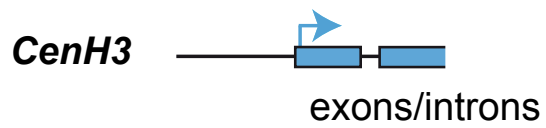

mRNA CenH3 poly A tail

CenH3 $3^{\text {CENP-A }}$

$$
\text { 1 }
$$

H3.3B CCAAT boxes

I mRNA H3.3

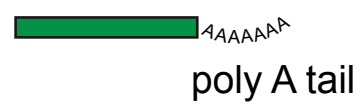

Throughout the cell cycle

G2/M phases 
Fig. 2.2

\section{A Alignment of human $\mathrm{H} 3.1, \mathrm{H} 3.2, \mathrm{H} 3.3$ and $\mathrm{CenH} 3^{\text {CENP-A }}$ amino acid sequences}

H3.1

H3.2

H3.3

CenH3 $3^{\text {CENP-A }}$

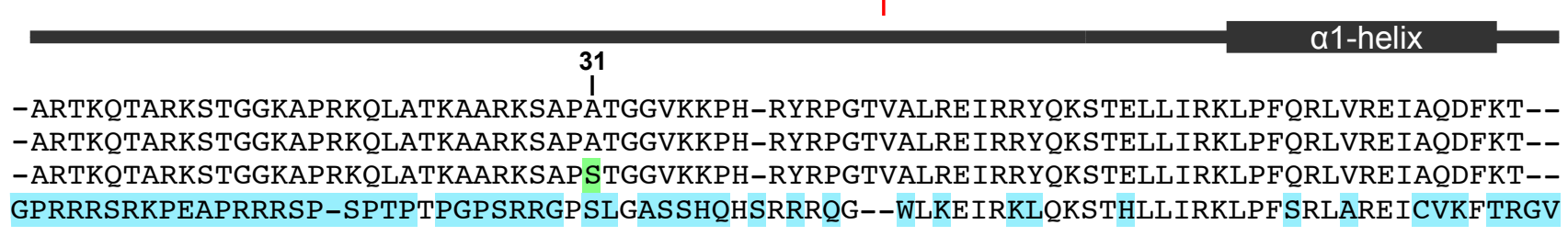

Histone fold domain

\section{B Crystal structures of $\mathrm{H} 3.1, \mathrm{H} 3.3$ and $\mathrm{CenH} 3^{\text {CENP-A }}$ nucleosome core particles}

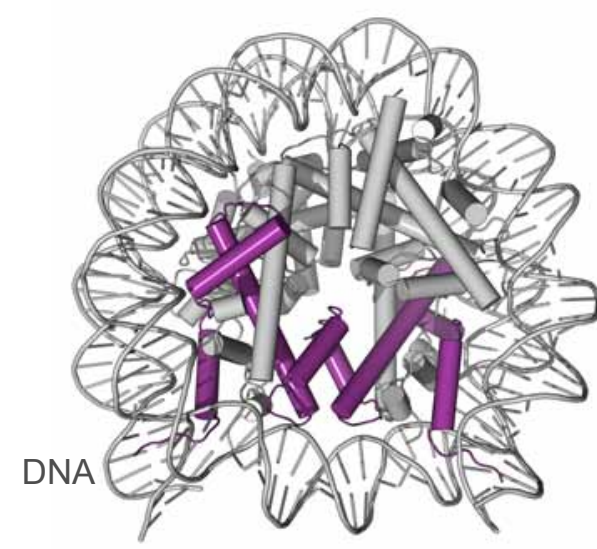

H3.1 core particle

(147 bp of DNA)

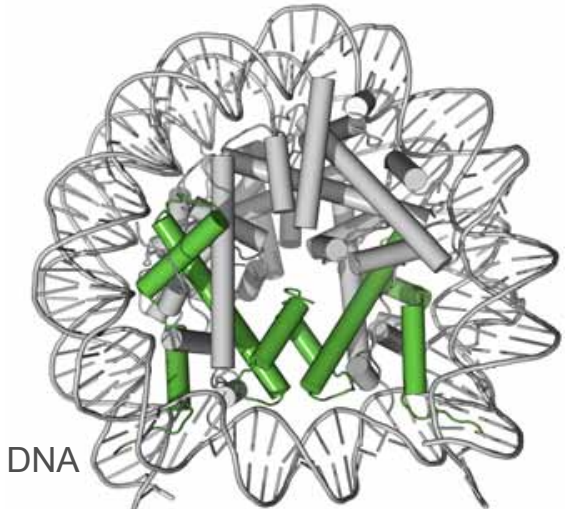

H3.3 core particle (147 bp of DNA)

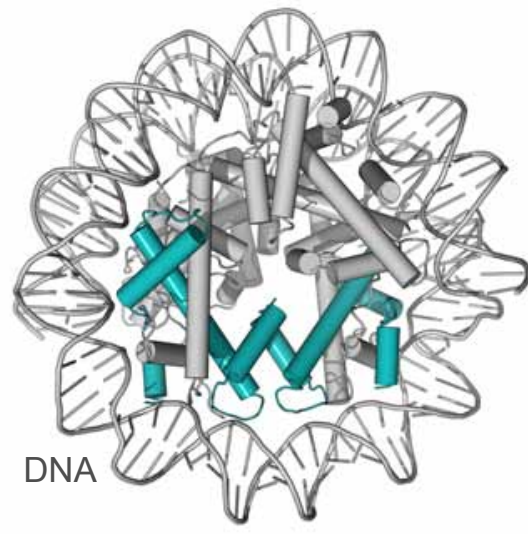

CenH3 $3^{\text {CENP-A }}$ core particle (121 bp of DNA) 
Fig. 2.3

New deposition of H3.1/2, H3.3 and CenH3 ${ }^{\text {CENP-A }}$ by their dedicated histone chaperones

Replicative H3

DNA Synthesis Coupled (DSC)
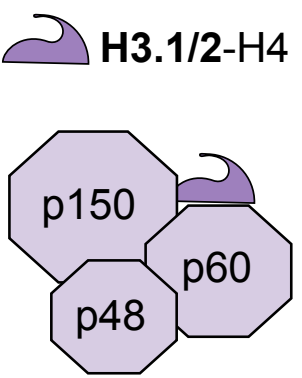

CAF-1 complex

H3 Variants

DNA Synthesis Independent (DSI)

D3.3-H4

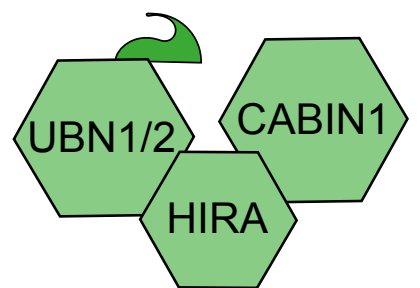

HIRA complex

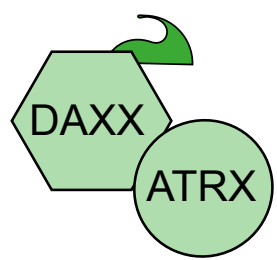

DAXX-ATRX $\int$ CenH3 $^{\text {CENP-A-H4 }}$

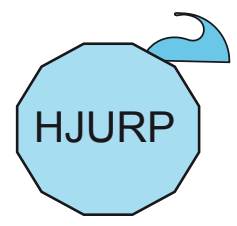

HJURP 
Fig. 2.4

A Genomic enrichment of $\mathrm{H} 3.1, \mathrm{H} 3.3$ and $\mathrm{CenH} 3^{\text {CENP-A }}$ mediated by their dedicated chaperones
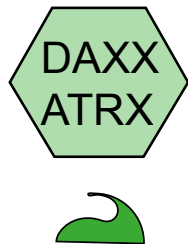

H3.3-H4

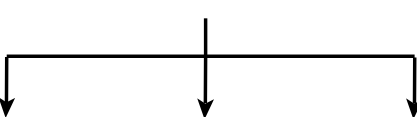

CenH3 ${ }^{\text {CENP-A }-H 4}$

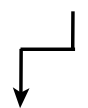

Regulatory Heterochromatin

Telomere elements pericentric centric
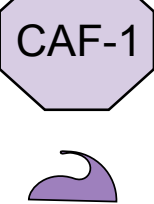

H3.1-H4

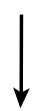

Replication \& Repair
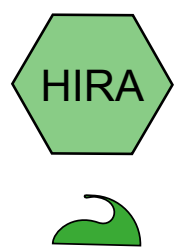

H3.3-H4

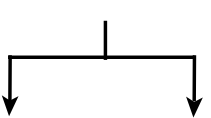

Gap-filling Active genes

\& Repair

\& Promoters

Telomere

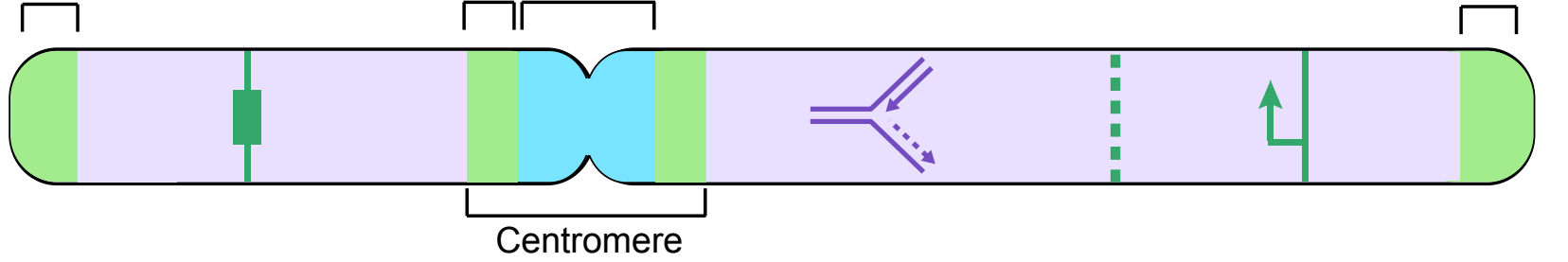

B Genomic distribution of $\mathrm{H} 3.1, \mathrm{H} 3.3$ and CenH3 ${ }^{\text {CENP-A }}$ from ChIP-Seq data in human cells

$\log _{2}$ ratio / input

H3.1-H4

H3.3-H4

CenH3 $3^{\text {CENP-A-H4 }}$

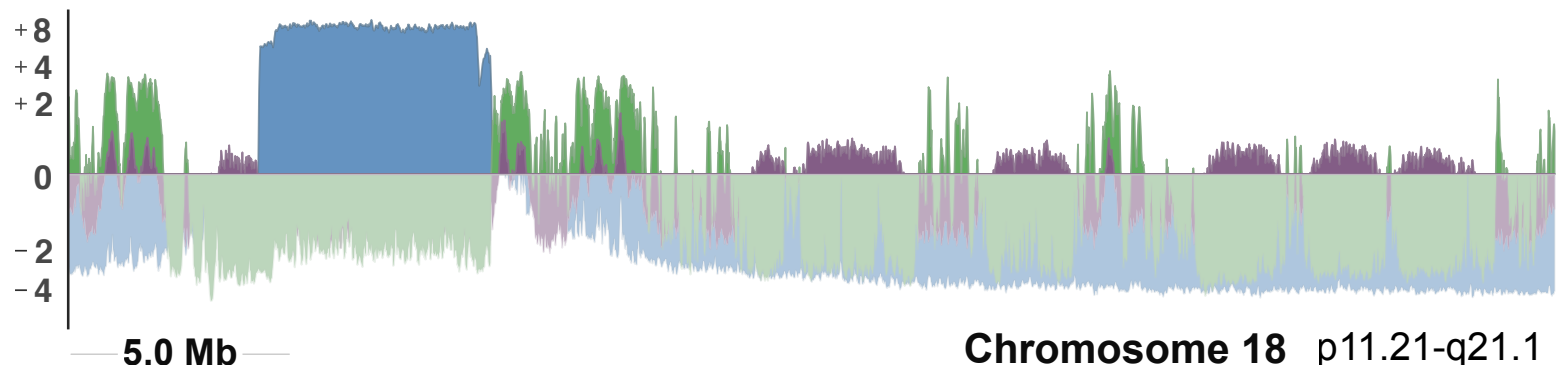


A Model for the dynamics of $\mathrm{H} 3-\mathrm{H} 4$ histones at the replication fork

Fig. 2.5

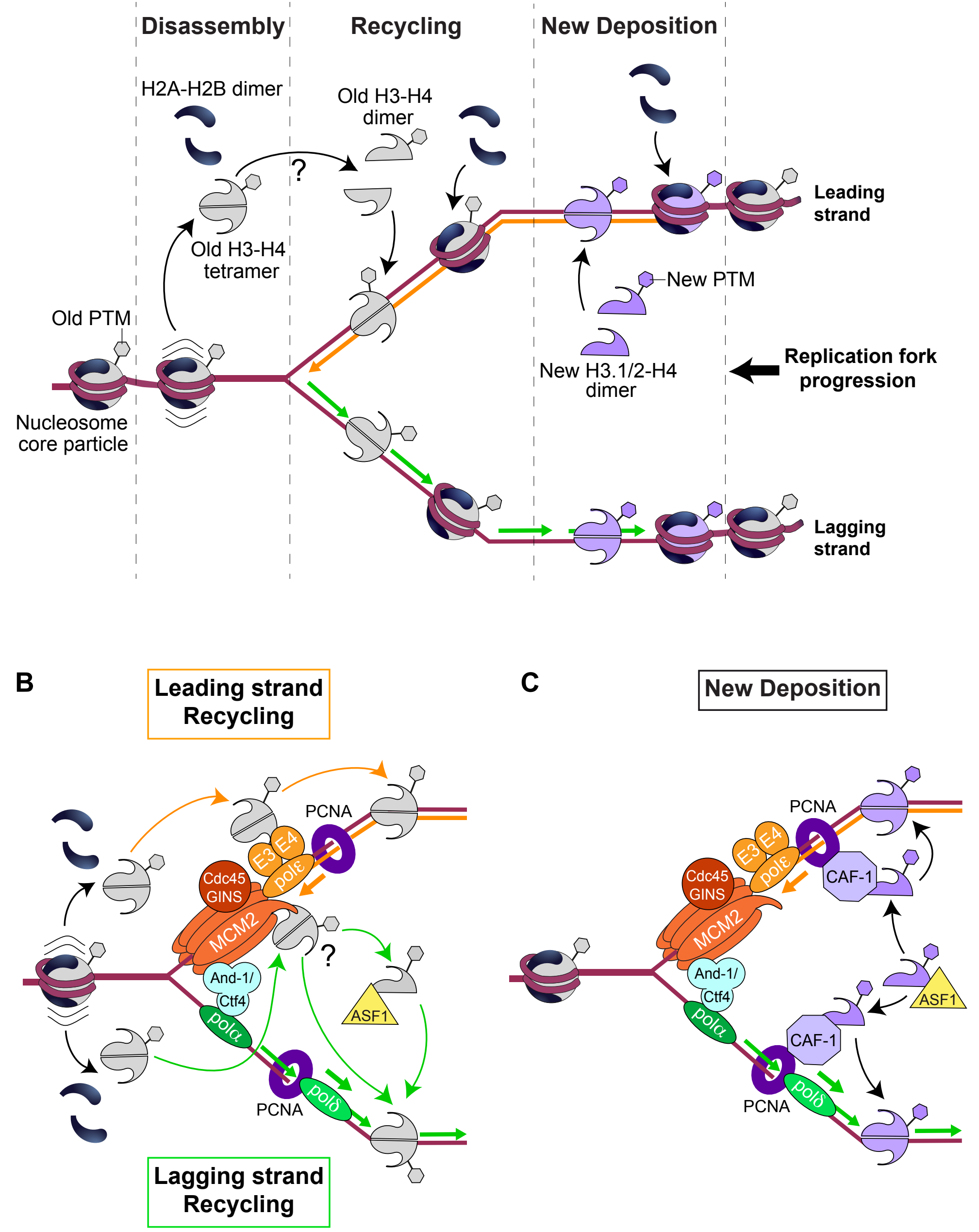

